\title{
Empirical investigation of barriers and drivers to the adoption of energy conservation measures, energy management practices and energy services in the Swedish iron and steel industry
}

Jean-Christian Brunke, Maria Johansson and Patrik Thollander

\section{Linköping University Post Print}

\section{Tweet}

N.B.: When citing this work, cite the original article.

Original Publication:

Jean-Christian Brunke, Maria Johansson and Patrik Thollander, Empirical investigation of barriers and drivers to the adoption of energy conservation measures, energy management practices and energy services in the Swedish iron and steel industry, 2014, Journal of Cleaner Production, (84), 509-525.

http://dx.doi.org/10.1016/j.jclepro.2014.04.078

Copyright: Elsevier

http://www.elsevier.com/

Postprint available at: Linköping University Electronic Press

http://urn.kb.se/resolve?urn=urn:nbn:se:liu:diva-113183 


\title{
Empirical investigation of barriers and drivers to the
}

\author{
adoption of energy conservation measures, energy
}

\section{management practices and energy services in the Swedish}

\section{iron and steel industry}

\author{
Jean-Christian Brunke $^{\mathrm{a}, *}$, Maria Johansson ${ }^{\text {b,c }}$, Patrik Thollander ${ }^{\text {b }}$ \\ a Institute for Energy Economics and the Rational Use of Energy (IER), University \\ of Stuttgart, DE-70565 Stuttgart, Germany \\ b Department of Management and Engineering, Division of Energy Systems, \\ Linköping University, SE-58183 Linköping, Sweden \\ ${ }^{c}$ Department of Technology and Built Environment, Division of Energy and \\ Mechanical Engineering, University of Gävle, SE-80176 Gävle, Sweden \\ Received
}

\begin{abstract}
The Swedish iron and steel industry is focused on the production of advanced steel grades and accounts for about 5\% of the country's final energy consumption. Energy efficiency is according to the European Commission a key element for the transition towards a resource-efficient economy. We investigated four aspects that are associated with the adoption of cost-effective energy conservation measures: barriers, drivers, energy management practices and energy services. We used questionnaires and followup telephone interviews to collect data from members of the Swedish steel association.

* Corresponding author. Tel.: +49-711-685 87838; Fax: +49-711-68587883

E-mail address: jean-christian.brunke@ier.uni-stuttgart.de (J. Brunke), maria.johansson@liu.se (M. Johansson), patrik.thollander@liu.se (P. Thollander).
\end{abstract}


The heterogeneous observations implied a classification into steel producers and downstream actors. For testing the significance, the Mann-Whitney U test was used. The most important barriers were internal economic and behavioural barriers. Energy service companies, in particular third-party financing, played a minor role. In contrast, high importance was attached to energy management as the most important drivers originated from within the company. Energy management practices showed that steel companies are actively engaged in the topic, but need to raise its prioritisation and awareness within the organisation. When sound energy management practices are included, the participants assessed the cost-effective energy conservation potential to be $9.7 \%$, which was $2.4 \%$ higher than the potential for solely adopting cost-effective technologies.

Keywords: Industrial energy efficiency; Barriers; Drivers; Energy management; ESCOs; Iron and steel

\section{Introduction and background}

Energy transformation and utilisation processes have a major part in anthropogenic greenhouse gas emissions. Energy efficiency is a smart way to accommodate simultaneously the three energy issues climate change, large-scale use of scarce resources and security of supply which have been prioritised by the European Union (EIPPCB 2009). The industrial sector is one of the highest energy-using sectors in the world. The improvement of industrial energy efficiency was accordingly identified as a key element to reduce the threat of increased global warming (IEA 2011). In the case of Sweden, industry accounts for $37 \%$ of final energy use of which $14 \%$ of total industrial energy use is represented by the iron and steel industry (ISI) (SEA 2013). An estimated $23 \%$ of all Swedish $\mathrm{CO}_{2}$ emissions are caused by fossil fuel- and electricity-intensive 
processes that are involved in the production of iron and steel (Johansson, Söderström 2011).

The Swedish ISI can be regarded as unique and difficult to compare with corresponding industries in other countries. The Swedish ISI is focused on the production of special steel grades and the respective companies are often world leaders in their market niches. The high degree of specialisation is accompanied by a higher specific energy consumption ${ }^{1}$ and a higher steel export rate than any other EU-27 country. Another unique aspect is that Sweden's historically low electricity prices influenced the ISI to favour electricity instead of other energy carriers which resulted in one of the highest ratio of electricity use to total energy use in Europe (Trygg and Karlsson, 2005). The ISI is further characterised by a high share of production processes and a high ratio of energy costs to total production costs which ambiguously influences the adoption rate of energy efficiency investments (Thollander, 2008).

Nowadays, the Swedish ISI is facing challenges such as rising electricity prices, growing international competition, the gloomy global economic situation and the effects of political instruments to limit $\mathrm{CO}_{2}$ emissions. Improving energy efficiency, i.e., the reduction of specific energy consumption which we now refer to as energy conservation (EC), is therefore of great importance from a company perspective as it would reduce production costs while increasing productivity and competiveness in the long run (Thollander et al., 2005; Galitsky et al., 2003; Worrell et al., 2001).

However, since the first two oil price crises, researchers discovered in various analyses that there existed an untapped potential of energy conservation measures (ECM) which were not adopted by actors although, according to techno-economic assessments,

\footnotetext{
${ }^{1}$ Although this term is thermodynamically incorrect, the word energy consumption is the widely used term, please see EN 16212:2012.
} 
they appeared to be cost-effective (Hirst and Brown, 1990). This discovered deviation between the optimal level of energy efficiency to the actual implemented level is named the energy efficiency gap or energy paradox and has been addressed frequently in the literature (e.g. Backlund et al., 2012b; Jaffe and Stavins, 1994; Hirst and Brown, 1990). As neoclassical economics describes actors as rational and self-interested, the gap is explained through the existence of market failures and barriers to the adoption of ECM. Backlund et al. (2012b) extend the traditional technology-related EC potential by including energy management practices. Besides, policies such as the directive 2012/27/EU (see EC 12/11/2012) identified energy service companies (ESCOs) as important change agents to overcome barriers. Together with drivers that facilitate the adoption of ECM, this study provides a comprehensive approach by looking at the aforementioned dimensions of EC in the Swedish ISI.

\section{Method and theory}

In order to investigate the dimensions identified in the introduction of EC in the Swedish ISI, we state the following research questions:

- What are the barriers to and drivers for the adoption of cost-effective ECM?

- What are the energy management practices with regard to investment criteria, long-term energy strategy, energy cost allocation, organisational factors and awareness campaigns?

- To what extent are Energy Service Companies (ESCOs) involved and what are the barriers to consulting them?

- What is the cost-effective EC potential in Sweden's ISI with regard to technology and management measures? 
To address the quantitative (e.g. EC potential) and qualitative nature (e.g. barriers, drivers) of the research questions, we chose a mixed method approach. First, we follow the basic approach of questionnaires which are used commonly in similar studies (e.g. Shi et al., 2008; Rohdin et al., 2007). Second, the results of the questionnaire are complemented by follow-up telephone conversations with straightforward note-taking (cf. Johansson and Söderström, 2011; Soroye and Nilsson, 2010; Bryman et al., 2008).

\subsection{Points of contact}

The Swedish steel producers' association, Jernkontoret, provided us with a list of contact details of energy managers in Swedish steel plants. The list was not exhaustive as not all members of Jernkontoret have an energy manager in place. We contacted the energy managers and remaining companies (see Jernkontoret, 2011). If the company has no energy manager, we asked, similar to Sivill et al. (2013), for the environmental, plant, production or technical development manager (see Table 1). Before sending the questionnaire (see section 2.2), we checked whether the point of contact is able to give sound answers to our questions. For instance, Ates and Durakbasa (2012) point out that in many industrial companies the official energy manager is not in charge of energy issues. We set the requirement that our point of contact must have profound technical knowledge of the production processes, energy consumptions and costs and be in charge, or at least involved, in the decision to invest in ECM.

Table 1: Position of the participants in the company's organisation

\begin{tabular}{rlrl}
\hline \hline Number & Questionnaire & Number & Follow-up telephone interviews \\
\hline 15 & Energy manager & 4 & Energy manager \\
4 & Production manager & 4 & Production manager \\
2 & Environmental manager & 0 & Environmental manager \\
2 & Research and development & 2 & Research and development \\
\hline 23 & Total & 10 & Total \\
\hline \hline
\end{tabular}




\subsection{Questionnaire}

In order to address the complexity and heterogeneity of energy flows in the ISI, we used questionnaires with follow-up telephone interviews to collect data. Although according to Yin (2003) case studies would give more detailed data and are therefore advantageous, we used questionnaires which allowed us to cover more industrial firms and derive generalisations. There are several guides available on how a questionnaire should be designed (e.g. Foddy, 2003; Burgess, 2001; Leung, 2001). In general, the questions should be short and simple, avoid scientific terms, ask for only one piece of information at a time and avoid unnecessary negatives in the sentence structure (Leung, 2001). Furthermore, all questions, except the EC potential (see section 6), are asked in a closed format so that a range of answers are presented and the questionnaire is easier to populate, evaluate and report. A key issue in the design of questionnaires is length (Foddy, 2003). The questionnaire consisted of five sections with a total length of five pages. In the first section, we collected background information on the position of the respondent in the organisation, number of employees, annual turnover and annual consumption of and expenditure on fuel and electricity (see Table 2). The four sections (barriers, drivers, energy management practices, ESCOs and EC potential) address the four research questions and are elaborated in the following four chapters. After a first test trail with three participants, we distributed the questionnaire between March and May 2012 to 46 companies.

\subsection{Follow-up telephone interviews}

After the responses to the questionnaire were analysed, we conducted telephone interviews to enhance the results and provide additional background for the discussion. 
Ten participants were selected (see Table 1) based on their experience with the topic (e.g. leading role at an energy manager network) or based on their responses (e.g. strong deviation from the average response). The interviews proved to be helpful in particular for energy management practices (see section 4), EC potential (see section 6) and the experiences with ESCOs (see section 5). We used a semi-structured approach for the interviews with a list of open and closed questions which reflected the responses in the questionnaire and position of the interviewee. The interviews were carried out in May 2012 with an average duration of 45 minutes. The results were captured with straightforward note-taking, because the interviewees felt uncomfortable having the interviews recorded or did not allow it.

\subsection{Description of the participating companies}

In total, we received 23 responses, i.e., half of the companies responded, which accounts for over $80 \%$ of the sector's total turnover. Compared to similar studies (e.g. Thollander and Ottosson, 2010; Rohdin et al., 2007; Groot et al., 2001), the response rate of $50 \%$ can be considered high. In order to respect the heterogeneity of the analysed industry, we divided the respondents into two categories: nine steel producers, i.e., companies that have at least a blast or electric arc furnace, and 14 downstream actors. Downstream actors are all companies that are listed by the Swedish Steel Producers' Association and do not have a blast or electric arc furnace. These companies usually receive the raw steel externally and process it further in hot and cold rolling mill operations. Results show that the average steel producer has a workforce two times larger, turnover three times higher, and electricity consumption three times higher and fuel consumption ten times higher compared to the average downstream actor (see Table 2). 
Table 2: Characterisation of the participating companies with regard to the two categories, namely steel producers and downstream actors, and the lower quartile $\left(\mathrm{Q}_{.25}\right)$, median $\left(\mathrm{Q}_{.50}\right)$ and upper quartile (Q.75) for the turnover, employees, fuel and electricity consumption and expenditure.

\begin{tabular}{|c|c|c|c|}
\hline & Quartile & Steel producers & $\begin{array}{l}\text { Downstream } \\
\text { actors }\end{array}$ \\
\hline $\begin{array}{l}\text { Number of participating } \\
\text { companies / total number }\end{array}$ & & $9 / 13$ & $14 / 33$ \\
\hline Turnover $\left[\mathrm{m} \mathrm{SEK}_{2012}\right]^{\mathrm{a}}$ & $\begin{array}{l}Q_{.25} \\
Q_{.50} \\
Q_{.75}\end{array}$ & $\begin{array}{l}5200 \\
7000 \\
8875\end{array}$ & $\begin{array}{c}272 \\
575 \\
1607\end{array}$ \\
\hline Employees & $\begin{array}{l}Q .25 \\
Q .50 \\
Q .75\end{array}$ & $\begin{array}{c}787 \\
1035 \\
1325\end{array}$ & $\begin{array}{c}65 \\
160 \\
280\end{array}$ \\
\hline Fuel consumption [TJ] & $\begin{array}{l}Q_{.25} \\
Q_{.50} \\
Q .75\end{array}$ & $\begin{array}{c}1071 \\
1305 \\
19462\end{array}$ & $\begin{array}{c}0.05 \\
0.3 \\
85\end{array}$ \\
\hline $\begin{array}{l}\text { Fuel expenditure }[\mathrm{m} \\
\left.\mathrm{SEK}_{2012}\right]^{\mathrm{a}}\end{array}$ & $\begin{array}{l}Q .25 \\
Q .50 \\
Q .75\end{array}$ & $\begin{array}{l}120 \\
150 \\
200\end{array}$ & $\begin{array}{c}4 \\
16 \\
19\end{array}$ \\
\hline $\begin{array}{l}\text { Electricity consumption } \\
{[\mathrm{TJ}]}\end{array}$ & $\begin{array}{l}Q_{.25} \\
Q_{.50} \\
Q .75\end{array}$ & $\begin{array}{c}756 \\
1386 \\
1440\end{array}$ & $\begin{array}{c}32 \\
90 \\
198\end{array}$ \\
\hline $\begin{array}{l}\text { Electricity expenditure [m } \\
\left.\text { SEK }_{2012}\right]^{\mathrm{a}}\end{array}$ & $\begin{array}{l}Q .25 \\
Q .50 \\
Q .75 \\
\end{array}$ & $\begin{array}{l}130 \\
175 \\
200 \\
\end{array}$ & $\begin{array}{c}6 \\
26 \\
34 \\
\end{array}$ \\
\hline
\end{tabular}
SEK/USD.

\subsection{Analysis}

To address the quantitative (e.g. EC potential) and qualitative nature (e.g. barriers, drivers) of the research questions, a mixed method approach was chosen. The advantages and disadvantages of qualitative compared to quantitative methods have been highlighted by several researchers (e.g. Pratt, 2007; Cassell, 2006; Foddy, 2003). In contrast to quantitative research, there is a lack of standard operating procedures in qualitative research, and in particular for the evaluation of results, that are commonly accepted among reviewers (Pratt 2007). For instance, Likert scales are used to assess attitudes 
towards barriers and drivers based on multidimensional underlying variables, e.g. five points from strongly disagree to highly agree. Although this scale is widely used in qualitative research, it is often treated with interval scale evaluation methods while being of clearly ordinal nature (Jamieson, 2004). For the evaluation of ordinal data we therefore use the median (the value that divides a ranked list into two halves), the mode (the most frequently occurring value), and the interquartile range (the difference between the upper quartile that splits $75 \%$ of the lowest observations and the lower quartile that splits $25 \%$ of the lowest of observations). In order to statistically validate the significance of deviations between steel producers and downstream actors (see Table 2), we use the Mann-Whitney $U$ test ${ }^{2}$ with a significance level of 0.05 . The barriers and drivers are ranked first after the mode and second after the percent rank, which is the percentage of respondents that ranked the specific issues with important (4) or very important (5) on the Likert scale.

\subsection{Limitations}

Surveys are accompanied by several limitations. Sampling errors and systematic bias can be minimised by a thorough selection of participants, design of the questionnaire and evaluation of the results (Gorard, 2003). Further, the biases of the respondents need to be addressed. For instance, the relationship between what respondents say they do and what they actually do is not very strong, or respondents tend to give answers even though they have little knowledge about the topic (Foddy, 2003). Particularly for the present survey, it is important to mention that the aggregation of attitudes, or Likert scales, is always accompanied by errors, plus the lack of standards for the evaluation of qualitative data

\footnotetext{
2 The Mann-Whitney or U-test is a null hypothesis significance test. It is used for testing the homogeneity between two independent distributions that belong to the same population. The significance test is failed if the calculated U-value is out of the range of the critical U-values. The latter depends on the size of the set and on the significance level. For the steel producers and downstream actors the lower and upper critical U-values are 31 and 95 with a significance level of 0.05 (see Reiczigel et al., 2005).
} 
leaves more room for mistakes (Pratt, 2007). The focus of Swedish firms on specialised steel grades might further limit the transferability to the ISI of other countries.

\section{Barriers}

As outlined in the introduction, the energy efficiency gap is commonly explained by the existence of barriers to the adoption of cost-effective ECM. Hence, barriers can be defined as all factors that hamper the adoption of cost-effective ECM or slow down their diffusion (Fleiter et al., 2011). Various surveys on barriers for specific industrial sectors and countries have been carried out. The identified barriers were manifold and in order to be able to formulate policy recommendations, the categorisation of barriers is a common approach in empirical investigations (see Table 3).

Table 3: Overview of selected surveys and case studies on the investigation of barriers to the adoption of cost-effective ECM in manufacturing firms. The table extends the approach of Fleiter et al. (2012).

\begin{tabular}{|c|c|c|c|c|}
\hline Study & Sector & Area & Categories & Main three barriers \\
\hline $\begin{array}{l}\text { (Harris et al., } \\
\text { 2000) }\end{array}$ & All sectors & Australia & None & $\begin{array}{l}\text { Low rates of return, } \\
\text { long payback periods, } \\
\text { auditors assessment } \\
\text { inaccurate }\end{array}$ \\
\hline $\begin{array}{l}\text { (Groot et al., } \\
\text { 2001) }\end{array}$ & $\begin{array}{l}\text { Chemical, } \\
\text { Basic metals, } \\
\text { Metal } \\
\text { products, } \\
\text { Horticulture, } \\
\text { Food, Paper }\end{array}$ & Netherlands & $\begin{array}{l}\text { General, } \\
\text { Financial, } \\
\text { Uncertainty, } \\
\text { Market related, } \\
\text { Policy related }\end{array}$ & $\begin{array}{l}\text { Other investments more } \\
\text { important, } \\
\text { technology can only be } \\
\text { implemented after } \\
\text { existing technology has } \\
\text { been replaced, } \\
\text { energy costs are not } \\
\text { sufficiently important }\end{array}$ \\
\hline $\begin{array}{l}\text { (Anderson } \\
\text { and Newell, } \\
2004 \text { ) }\end{array}$ & $\begin{array}{l}\text { Manufacturing } \\
\text { SMEs }\end{array}$ & USA & $\begin{array}{l}\text { Economic, } \\
\text { Institutional, } \\
\text { Financing }\end{array}$ & $\begin{array}{l}\text { Too expensive initially, } \\
\text { lack staff for } \\
\text { analysis/implementation, } \\
\text { cash flow prevents } \\
\text { implementation }\end{array}$ \\
\hline $\begin{array}{l}\text { (Rohdin and } \\
\text { Thollander, } \\
\text { 2006) }\end{array}$ & $\begin{array}{l}\text { Non-energy- } \\
\text { intensive } \\
\text { manufacturing }\end{array}$ & Sweden & $\begin{array}{l}\text { Economic non-market } \\
\text { failure, } \\
\text { Economic market } \\
\text { failure, } \\
\text { Behavioural, } \\
\text { Organisational } \\
\text { (based on Sorrell et al., } \\
2000 \text { ) }\end{array}$ & $\begin{array}{l}\text { Cost of production } \\
\text { disruption/ hassle/ } \\
\text { inconvenience, } \\
\text { lack of time or other } \\
\text { priorities, } \\
\text { cost of obtaining } \\
\text { information about the }\end{array}$ \\
\hline
\end{tabular}


(Nagesha and Balachandra, 2006)

$\begin{aligned} & \text { (Thollander } \\ & \text { et al., 2007) }\end{aligned}$ SMEs

$\begin{aligned} & \text { (Rohdin et } \\ & \text { al., 2007) }\end{aligned}$

(Thollander and Ottosson, 2008)

(Shi et al., SMEs
2008)

$\begin{array}{ll}\text { (Sardianou, } & \text { Metals, } \\ \text { 2008) } & \text { Machinery, } \\ & \text { Food/Drink, } \\ & \text { Chemicals, }\end{array}$

Paper, Textiles

(Ren, 2009) Petrochemica

(Currás, 2010)

Karnataka, India

Sweden

Sweden 


\begin{tabular}{|c|c|c|c|c|}
\hline & & & $\begin{array}{l}\text { (based on Sorrell et al., } \\
\text { 2000) }\end{array}$ & $\begin{array}{l}\text { rules of investment } \\
\text { decision making, } \\
\text { technology fitting in } \\
\text { actual process }\end{array}$ \\
\hline $\begin{array}{l}\text { (Okazaki and } \\
\text { Yamaguchi, } \\
\text { 2011) }\end{array}$ & ISI & Japan & $\begin{array}{l}\text { Economic, } \\
\text { Inadequate national } \\
\text { policies and regulations, } \\
\text { Technological issues, } \\
\text { Others }\end{array}$ & $\begin{array}{l}\text { Other priority for financial } \\
\text { investment, } \\
\text { inadequate national } \\
\text { policies and regulations, } \\
\text { technology not applicable } \\
\text { to process }\end{array}$ \\
\hline $\begin{array}{l}\text { (Fleiter et al., } \\
\text { 2012) }\end{array}$ & SMEs & Germany & $\begin{array}{l}\text { Imperfect information, } \\
\text { Hidden costs, } \\
\text { Risk, } \\
\text { Access to capital, } \\
\text { Split incentives, } \\
\text { Bounded rationality } \\
\text { (based on Sorrell et al., } \\
2000 \text { ) }\end{array}$ & $\begin{array}{l}\text { Investment costs too high, } \\
\text { other investments have } \\
\text { higher priority, } \\
\text { measure not profitable }\end{array}$ \\
\hline $\begin{array}{l}\text { (Trianni and } \\
\text { Cagno, 2012) }\end{array}$ & $\begin{array}{l}\text { Non-energy- } \\
\text { intensive } \\
\text { manufacturing } \\
\text { SMEs }\end{array}$ & $\begin{array}{l}\text { Northern } \\
\text { Italy }\end{array}$ & $\begin{array}{l}\text { Skills, } \\
\text { Information Resources, } \\
\text { Awareness }\end{array}$ & $\begin{array}{l}\text { Access to capital, } \\
\text { Scarce information } \\
\text { regarding energy } \\
\text { efficiency opportunities } \\
\text { and winning solutions, } \\
\text { Poor information for the } \\
\text { energy efficiency } \\
\text { decisions }\end{array}$ \\
\hline $\begin{array}{l}\text { (Walsh and } \\
\text { Thornley, } \\
\text { 2012) }\end{array}$ & $\begin{array}{l}\text { Process } \\
\text { industries with } \\
\text { a focus on low } \\
\text { grade heat } \\
\text { utilisation }\end{array}$ & UK & $\begin{array}{l}\text { Structural, } \\
\text { Market, } \\
\text { Interaction, } \\
\text { Performance }\end{array}$ & $\begin{array}{l}\text { Availability of appropriate } \\
\text { infrastructure, } \\
\text { utilisation of low grade } \\
\text { heat, } \\
\text { high capital costs }\end{array}$ \\
\hline $\begin{array}{l}\text { (Trianni et } \\
\text { al., 2013a) }\end{array}$ & Foundry & $\begin{array}{l}\text { Finland, } \\
\text { France, } \\
\text { Germany, } \\
\text { Italy, } \\
\text { Poland, } \\
\text { Spain, and } \\
\text { Sweden }\end{array}$ & $\begin{array}{l}\text { Economic non-market } \\
\text { failure, } \\
\text { Economic market } \\
\text { failure, } \\
\text { Behavioural, } \\
\text { Organisational } \\
\text { (based on Sorrell et al., } \\
2000 \text { ) }\end{array}$ & $\begin{array}{l}\text { Lack of budget funding, } \\
\text { other priorities for capital } \\
\text { investments, } \\
\text { lack of time or other } \\
\text { priorities }\end{array}$ \\
\hline $\begin{array}{l}\text { (Trianni et } \\
\text { al., 2013b) }\end{array}$ & $\begin{array}{l}\text { Primary metal } \\
\text { manufacturing } \\
\text { SMEs }\end{array}$ & $\begin{array}{l}\text { Northern } \\
\text { Italy }\end{array}$ & $\begin{array}{l}\text { Technology-related, } \\
\text { Information, } \\
\text { Economic, } \\
\text { Behavioural, } \\
\text { Organisational, } \\
\text { Related to } \\
\text { competencies, } \\
\text { Awareness } \\
\text { (based on Cagno et al., } \\
\text { 2013) }\end{array}$ & $\begin{array}{l}\text { Information issues on } \\
\text { energy contracts, } \\
\text { lack of interest in energy- } \\
\text { efficiency interventions, } \\
\text { hidden costs }\end{array}$ \\
\hline $\begin{array}{l}\text { (Trianni et } \\
\text { al., 2013c) }\end{array}$ & $\begin{array}{l}\text { Manufacturing } \\
\text { SMEs }\end{array}$ & $\begin{array}{l}\text { Northern } \\
\text { Italy }\end{array}$ & $\begin{array}{l}\text { Technology-related, } \\
\text { Information, } \\
\text { Economic, }\end{array}$ & $\begin{array}{l}\text { Investment costs, } \\
\text { information issues on } \\
\text { energy contracts, }\end{array}$ \\
\hline
\end{tabular}




\begin{tabular}{|c|c|c|c|c|}
\hline & & & $\begin{array}{l}\text { Behavioural, } \\
\text { Organisational, } \\
\text { Related to competences, } \\
\text { Awareness } \\
\text { (based on Cagno et al., } \\
2013 \text { ) }\end{array}$ & hidden costs \\
\hline $\begin{array}{l}\text { (Wentemi } \\
\text { Apeaning } \\
\text { and } \\
\text { Thollander, } \\
\text { 2013) }\end{array}$ & $\begin{array}{l}\text { Selected } \\
\text { industries (Iron } \\
\text { and Steel, } \\
\text { Aluminium, } \\
\text { Food, Plastics, } \\
\text { Chemicals) }\end{array}$ & Ghana & $\begin{array}{l}\text { Access to capital, } \\
\text { Hidden costs, } \\
\text { Heterogeneity, } \\
\text { Risk, } \\
\text { Imperfect information, } \\
\text { Split incentives }\end{array}$ & $\begin{array}{l}\text { Lack of budget funding, } \\
\text { access to capital, } \\
\text { other priorities for capital } \\
\text { investment }\end{array}$ \\
\hline $\begin{array}{l}\text { (Venmans, } \\
\text { 2014) }\end{array}$ & $\begin{array}{l}\text { Ceramic, } \\
\text { Cement, Lime }\end{array}$ & Belgium & $\begin{array}{l}\text { Hidden costs, } \\
\text { Risk and uncertainty, } \\
\text { Imperfect information, } \\
\text { Split incentives, } \\
\text { Capital budgeting, } \\
\text { Bounded rationality } \\
\text { (based on Sorrell et al., } \\
2004 \text { ) }\end{array}$ & $\begin{array}{l}\text { Other priorities for capital } \\
\text { investments, } \\
\text { hidden costs, } \\
\text { technical feasibility } \\
\text { wasn't studied before }\end{array}$ \\
\hline
\end{tabular}

Although different taxonomies emerged over time, the majority of the studies based their categorisation on the Sorrell et al. (2000) taxonomy (see Table 3). Cagno et al. (2013) identified several issues (e.g. missing elements, overlaps and implicit interaction) in the current approaches and suggested a novel taxonomy. For our study, we complement the barriers identified for Swedish industry (Palm and Thollander, 2010; Thollander and Ottosson, 2008; Rohdin et al., 2007) with the barriers for the steel sector of the members of the Asia-Pacific Partnership on Clean Development and Climate (Okazaki and Yamaguchi, 2011) and barriers for foundries in different European countries (Trianni et al., 2013) and categorise them with the Cagno et al. (2013) taxonomy (see Table 4).

Table 4: Investigated barriers to the adoption of cost-effective ECM for the Swedish ISI (adapted from Trianni et al., 2013a; Okazaki and Yamaguchi, 2011; Palm and Thollander, 2010; Thollander and Ottosson, 2008; Thollander et al., 2007; Rohdin and Thollander, 2006) and their categorisation based on the Cagno et al. (2013) taxonomy

\begin{tabular}{lll}
\hline \hline Origin & Area & Barriers \\
\hline External & Market & Poor information quality regarding ECM
\end{tabular}




$\begin{array}{lll} & \text { No cost-effective technological ECM available } \\ \text { Mnternal } & \text { Awareness } & \text { Uncertainty about future energy prices and fiscal policies } \\ \text { Behavioural } & \text { Lack of staff awareness or motivation } \\ & \text { Insufficient top management support } \\ \text { Competences } & \text { Lack of time or other priorities } \\ & \text { Lack of information about allocation of energy costs } \\ \text { Economic } & \text { Lack of technical skills } \\ & \text { Limited access to capital } \\ & \text { Uncertainties regarding hidden costs } \\ & \text { Other priorities for financial investments } \\ & \text { Technical risks (e.g. production failure) } \\ & \text { No options to improve energy management practices } \\ \text { Organisational } & \text { Difficulty to cooperate inter-divisional } \\ & \text { Limited authority of energy manager } \\ & \end{array}$

In the questionnaire, we listed the barriers according to the categories with a brief introduction to that field based on Thollander (2008) and asked the participants directly how they value the importance of the adoption of cost-effective ECM in their company on a Likert scale from not important (1) to very important (5). We refrained from asking technology-specific questions due to the heterogeneous nature of the Swedish steel sector. 


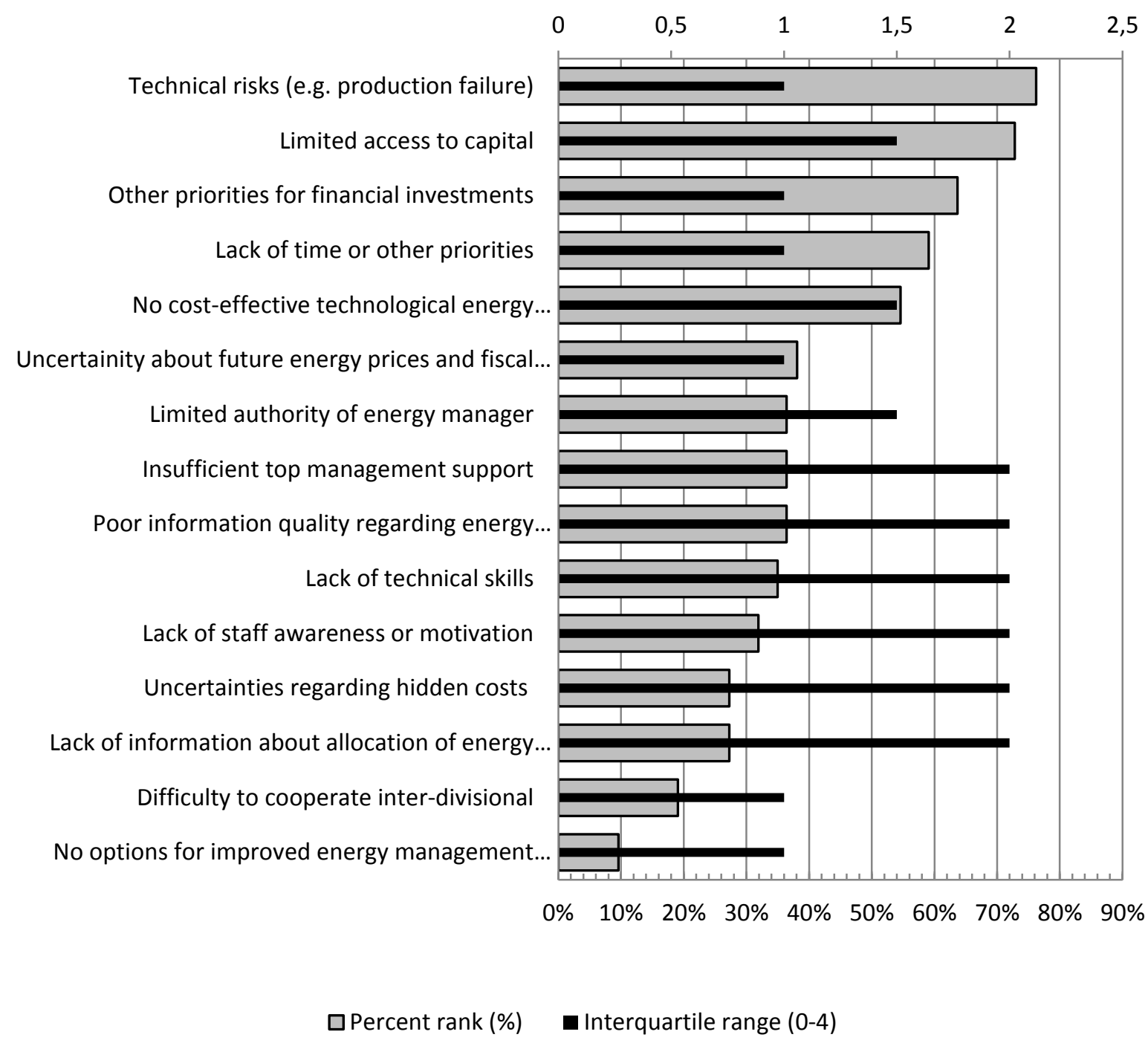

Figure 1: Barriers to the adoption of cost-effective ECM in the Swedish ISI ranked first after the mode and second after the percent rank. The percent rank displays the percentage of respondents that rated that barrier as important (4 on the Likert scale) or very important (5). The interquartile range (0-

4) indicates the dispersion of the responses and is calculated as the difference between the upper quartile $\mathrm{Q}_{.75}$ and the lower quartile $\mathrm{Q} .25$.

The participants perceived technical risks (e.g. production failures) as the most important barrier to the adoption of cost-effective ECM in the Swedish ISI (see Figure 1). The same significant importance was identified for Swedish Foundry and Pulp and Paper industry (see Table 3). All three sectors operate on a continuous basis and the majority of the value added is generated by production processes. Production failures or quality losses, which are also covered by this barrier, are thus of comparatively higher 
concern. Other studies on process industries (e.g. Venmans, 2014; Trianni et al., 2013a) address disruption and quality loss costs as hidden costs during implementation. However, with the exception of Trianni et al. (2013c), in none of the surveys do hidden costs receive the same importance as technical risks. As hidden costs consist of the costs pre, during, or post the adoption of the measures (Trianni et al., 2013c), the comparability to technical risks in other studies is thus limited. Besides technical risks, limited access to capital and other priorities for financial investment are ranked by the participants as second and third most important barriers. These barriers received the same importance in the majority of other empirical investigations on barriers and have been extensively discussed (see Table 3). The low interquartile ranges (1-1.5) indicate a low dispersion among the respondents and support the importance of these barriers. It should be noted that the comparisons of the results are to some extent limited due to the differences of the investigated sectors in terms of production process, number of employees and turnover. The lowest ranked barrier no options to improve energy management practices was included in the questionnaire as a consistency check for the investigation of energy management practices (see section 4) and organisational EC potential (see section 6). The low ranking does not contradict the results obtained in these sections. 


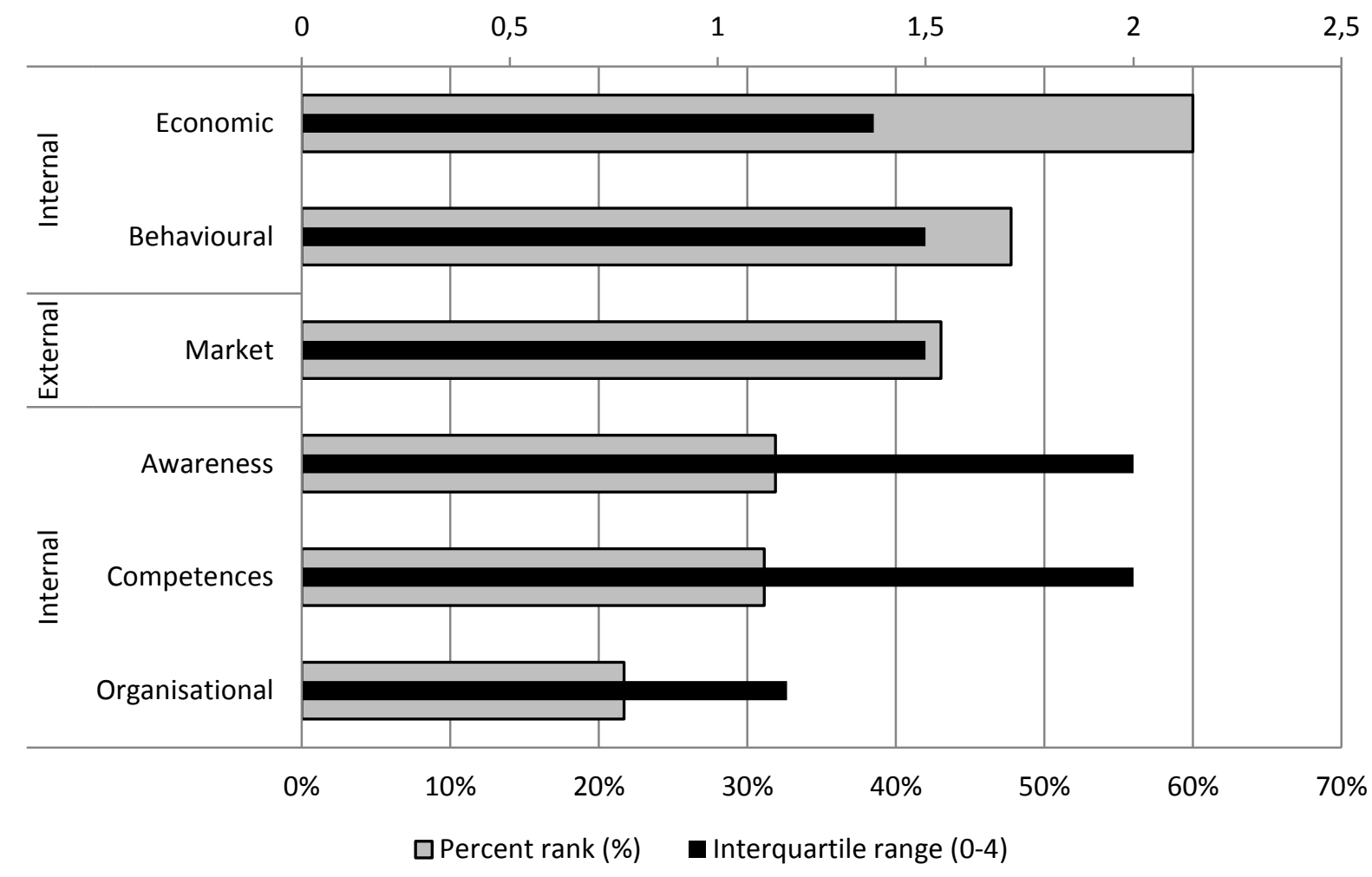

Figure 2: Barriers to the adoption of cost-effective EC technologies categorised according to the origin with respect to firm and areas (see Table 4). The areas are ranked by the percent rank (see Figure 1).

The classification of the results according to the Cagno et al. (2013) taxonomy gives a distinct overview of the origin and the areas that are affected by the barriers. The three barriers perceived as most important - technical risks, limited access to capital and other priorities for financial investments - can be related to economic aspects (see Table 4). Accordingly, the economic barriers are ranked highest (see Figure 2). In the follow-up telephone interviews, interviewees stated that, due to the high specialisation and affiliated international market orientation, Sweden's steel industry in 2012 was still experiencing the effects of the global financial crisis. Thus, companies are focusing on the core business so that the capital and profitability requirements for EC investments are tightened. In contrast to Trianni et al. (2013c), where the behavioural barriers were ranked lowest, half of the Swedish steel producers and downstream actors ranked them as important. Market barriers were ranked by the participants as third most important 
which allows, according to neoclassical economic theory, the formulation of political interventions to address them.

In order to respect the heterogeneity of steel producers and downstream actors (see section 2), we investigated further divergences between the two groups with a significance level of 0.05 (see Figure 3). The barrier technical risks is of high concern for $87 \%$ of the steel producers compared to $67 \%$ of the downstream actors, which can be explained by the integrated production and more complex processes that are involved in the manufacturing of steel (Mann-Whitney $\mathrm{U}=60.5, \mathrm{n}_{\text {Downstream actor }}=14, \mathrm{n}_{\text {Steel producer }}=9$, $\mathrm{P}<0.05$ two-tailed). In contrast, the downstream actors rated the limited access to capital barrier higher $(U=47)$ as their lower turnover might reduce the ability to acquire funds (see Table 2). Further, downstream actors ranked the barrier lack of technical skills as important or very important $(U=40)$ which can be linked to the smaller workforce (see Table 2) and with specific higher efforts to employ an energy manager or train existing personnel.

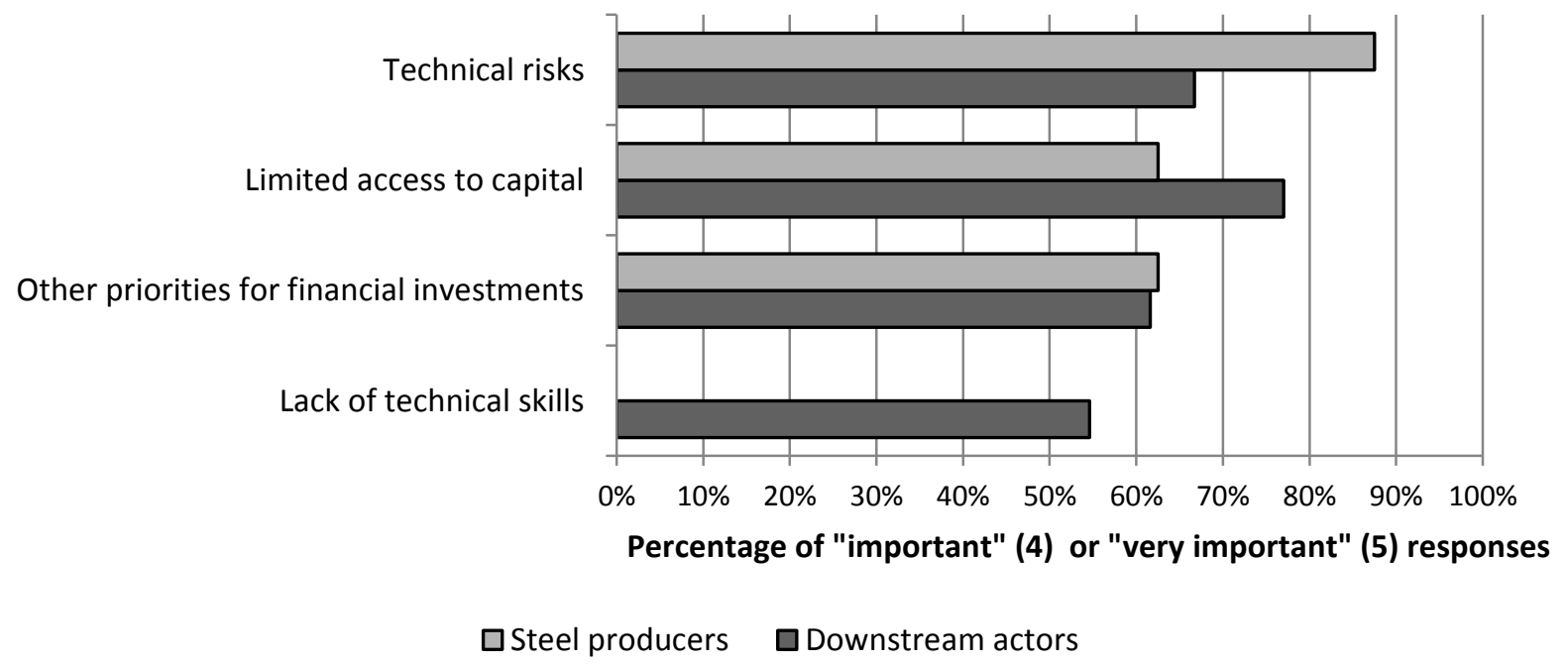

Figure 3: Divergences with a significance level of 0.05 in the responses from steel production and downstream actors to the adoption of cost-effective ECM in the Swedish ISI.

\section{Drivers}


While barriers are widely investigated in various sectors and countries (see Table 3 ), only a few empirical investigations of the driving forces for consumers to adopt costeffective ECM have been conducted so far (see Table 5). For instance, Trianni et al. (2013c) "call for future research in the world of drivers to energy efficiency with much greater efforts on empirical studies". In the light of recent research to include energy management practices (e.g. Backlund et al., 2012b), Cagno and Trianni (2013) define drivers as "factors facilitating the adoption of both energy-efficient technologies and practices, thus going beyond the view of investments and including the promotion of an energy-efficient culture and awareness".

Table 5: Overview of selected surveys and case studies on the investigation of drivers for the adoption of cost-effective ECM in manufacturing firms.

\begin{tabular}{|c|c|c|c|c|}
\hline Study & Sector & Area & Categories & $\begin{array}{l}\text { Main three } \\
\text { drivers }\end{array}$ \\
\hline $\begin{array}{l}\text { (Rohdin and } \\
\text { Thollander, 2006) }\end{array}$ & $\begin{array}{l}\text { Non-energy- } \\
\text { intensive } \\
\text { manufacturing }\end{array}$ & Sweden & None & $\begin{array}{l}\text { Long-term } \\
\text { energy strategy, } \\
\text { increasing energy } \\
\text { prices, } \\
\text { people with real } \\
\text { ambition }\end{array}$ \\
\hline $\begin{array}{l}\text { (Thollander et al., } \\
\text { 2007) }\end{array}$ & $\begin{array}{l}\text { Manufacturing } \\
\text { SMEs }\end{array}$ & Sweden & None & $\begin{array}{l}\text { Long-term } \\
\text { strategy, } \\
\text { people with real } \\
\text { ambition, } \\
\text { environmental } \\
\text { company profile } \\
\text { and/or EMS }\end{array}$ \\
\hline $\begin{array}{l}\text { (Rohdin et al., } \\
\text { 2007) }\end{array}$ & Foundry & Sweden & None & $\begin{array}{l}\text { Long-term } \\
\text { strategy, } \\
\text { people with real } \\
\text { ambition, } \\
\text { environmental } \\
\text { company profile }\end{array}$ \\
\hline $\begin{array}{l}\text { (Thollander and } \\
\text { Ottosson, 2008) }\end{array}$ & Pulp and Paper & Sweden & $\begin{array}{l}\text { Market-related driving } \\
\text { forces, } \\
\text { Policy Instruments, } \\
\text { Potential energy } \\
\text { policies, } \\
\text { Behavioural and } \\
\text { organisational-related }\end{array}$ & $\begin{array}{l}\text { Cost reductions } \\
\text { resulting from } \\
\text { lower energy use, } \\
\text { people with real } \\
\text { ambition, } \\
\text { long-term energy } \\
\text { strategy }\end{array}$ \\
\hline
\end{tabular}




\begin{tabular}{|c|c|c|c|c|}
\hline (Ren, 2009) & Petrochemicals & OECD & None & $\begin{array}{l}\text { Process energy } \\
\text { cost savings, } \\
\text { tight supply of } \\
\text { gas feedstock, } \\
\text { personal } \\
\text { commitment of } \\
\text { individuals }\end{array}$ \\
\hline $\begin{array}{l}\text { (Cagno and } \\
\text { Trianni, 2013) }\end{array}$ & $\begin{array}{l}\text { Manufacturing } \\
\text { SMEs }\end{array}$ & Italy & $\begin{array}{l}\text { Action required } \\
\text { (Regulation, Economics, } \\
\text { Information), } \\
\text { Origin (Within, Outside) }\end{array}$ & $\begin{array}{l}\text { Allowances or } \\
\text { public financing, } \\
\text { external } \\
\text { pressures, } \\
\text { long-term } \\
\text { benefits }\end{array}$ \\
\hline $\begin{array}{l}\text { (Thollander et al., } \\
\text { 2013) }\end{array}$ & Foundry & $\begin{array}{l}\text { Finland, } \\
\text { France, } \\
\text { Germany, } \\
\text { Italy, Poland, } \\
\text { Spain, and } \\
\text { Sweden }\end{array}$ & $\begin{array}{l}\text { Financial, } \\
\text { Informational, } \\
\text { Organisational, } \\
\text { External }\end{array}$ & $\begin{array}{l}\text { Cost reductions, } \\
\text { threat of rise in } \\
\text { energy prices and } \\
\text { energy taxes, } \\
\text { commitment by } \\
\text { top management }\end{array}$ \\
\hline $\begin{array}{l}\text { (Wentemi } \\
\text { Apeaning and } \\
\text { Thollander, 2013) }\end{array}$ & $\begin{array}{l}\text { Selected } \\
\text { industries (steel, } \\
\text { aluminium, food, } \\
\text { plastics, } \\
\text { chemicals) }\end{array}$ & Ghana & $\begin{array}{l}\text { Access to capital, } \\
\text { Hidden costs, } \\
\text { Heterogeneity, } \\
\text { Risk, } \\
\text { Imperfect information, } \\
\text { Split incentives }\end{array}$ & $\begin{array}{l}\text { Lack of budget } \\
\text { funding, } \\
\text { access to capital, } \\
\text { other priorities } \\
\text { for capital } \\
\text { investment }\end{array}$ \\
\hline (Venmans, 2014) & $\begin{array}{l}\text { Ceramic, cement, } \\
\text { lime }\end{array}$ & Belgium & $\begin{array}{l}\text { Economic reasons, } \\
\text { Policy, } \\
\text { Management }\end{array}$ & $\begin{array}{l}\text { Increasing energy } \\
\text { prices, } \\
\text { commitment by } \\
\text { top management, } \\
\text { environmental } \\
\text { image }\end{array}$ \\
\hline
\end{tabular}

In line with Reddy (2013), who suggests extending the analysis of barriers to the study of drivers, Thollander and Ottosson (2008) categorised the drivers for the Swedish pulp and paper industry into market-related driving forces, policy instruments, potential energy policies and behavioural and organisational-related drivers. In our study, we include the drivers of Thollander and Ottosson (2008) into the action-oriented classification of Cagno and Trianni (2013) (see Table 6). 
Table 6: Investigated drivers for the adoption of cost-effective ECM for the Swedish ISI (adapted from Thollander and Ottosson, 2008) with categorisation based on Cagno and Trianni (2013)

\begin{tabular}{|c|c|c|}
\hline $\begin{array}{l}\text { Action required } \\
\text { (R=Regulation, } \\
\mathrm{E}=\text { Economics, } \\
\mathrm{I}=\text { Information) }\end{array}$ & $\begin{array}{l}\text { Origin } \\
\text { (W=Within, } \\
\mathrm{O}=\text { Outside) }\end{array}$ & Driver \\
\hline $\mathrm{E}$ & $\mathrm{O}$ & Third-party financing (TPF) \\
\hline $\mathrm{E}$ & $\mathrm{O}$ & International competition \\
\hline $\mathrm{E}$ & $\mathrm{O}$ & Threat of rising energy prices \\
\hline $\mathrm{E}$ & $\mathrm{W}$ & Long-term energy strategy \\
\hline $\mathrm{E}$ & $\mathrm{W}$ & Cost reduction resulting from lower energy use \\
\hline I & $\mathrm{O}$ & Pressure from customers and NGOs \\
\hline I & $\mathrm{W}$ & Networks within the sector \\
\hline I & $\mathrm{W}$ & Local authority energy consultancy \\
\hline I & $\mathrm{W}$ & Support from energy experts \\
\hline I & $\mathrm{W}$ & Demand from owner \\
\hline I & $\mathrm{W}$ & Support from the sector organisation \\
\hline I & $\mathrm{W}$ & People with real ambition \\
\hline I & $\mathrm{W}$ & Commitment from top management \\
\hline $\mathrm{R}$ & $\mathrm{O}$ & Energy audit subsidy \\
\hline $\mathrm{R}$ & $\mathrm{O}$ & Beneficial loans for energy efficiency investments \\
\hline $\mathrm{R}$ & $\mathrm{O}$ & Investment subsidies for energy efficiency technologies \\
\hline $\mathrm{R}$ & $\mathrm{O}$ & Electricity Certificate System (ECS) \\
\hline $\mathrm{R}$ & $\mathrm{O}$ & Taxes (e.g. energy, $\mathrm{CO}_{2}$ ) \\
\hline $\mathrm{R}$ & $\mathrm{O}$ & European Emission Trading Scheme (EU ETS) \\
\hline $\mathrm{R}$ & $\mathrm{O}$ & Long-term agreements with tax exemption (PFE) \\
\hline $\mathrm{R}$ & $\mathrm{O}$ & Regulations (e.g. Swedish Environmental Code) \\
\hline
\end{tabular}

The most important driver for the adoption of cost-effective ECM is the commitment from top management, because it has a mode of five (very important) which is the highest characteristic value in the questionnaire. Only Venmans (2014) has identified a similar importance of the recent contributions to that field (see Table 5). However, the comparison is limited, as not all studies have addressed this driver in particular. Instead, the driver people with real ambition, which is here ranked as fourth, addresses the commitment from top management as well (see Thollander and Ottosson, 2008). Moreover, recent studies used average values for ranking which differ from our approach and might impact the ranking (see section 2.5) Still, the high importance and the fact that 
on average, the involvement of top operations managers increase the percentage of recommended ECM that are implemented by $13.4 \%$ (Blass et al., 2014), speaks for a separate investigation of people with real ambition and commitment from top management. Cagno and Trianni (2013) used the term management sensitivity to address this issue which was ranked as sixth of all 14 perceived drivers. Although the cost reduction driver has the highest percent rank, it is ranked second, because it has a lower mode of four. Similar to the barriers, the responses of the lowest and highest ranked drivers have a low dispersion. In particular, the long-term energy strategy driver was rated by 14 respondents as important, which represents more than $50 \%$ of all responses and results in an interquartile range of zero. In other words, "the existence of a long-term energy strategy is an important driving force for the adoption of cost-effective ECM in the Swedish steel industry" is the most definite answer in the questionnaire. For further information on specific drivers, we refer to the respective literature (see Table 5). 


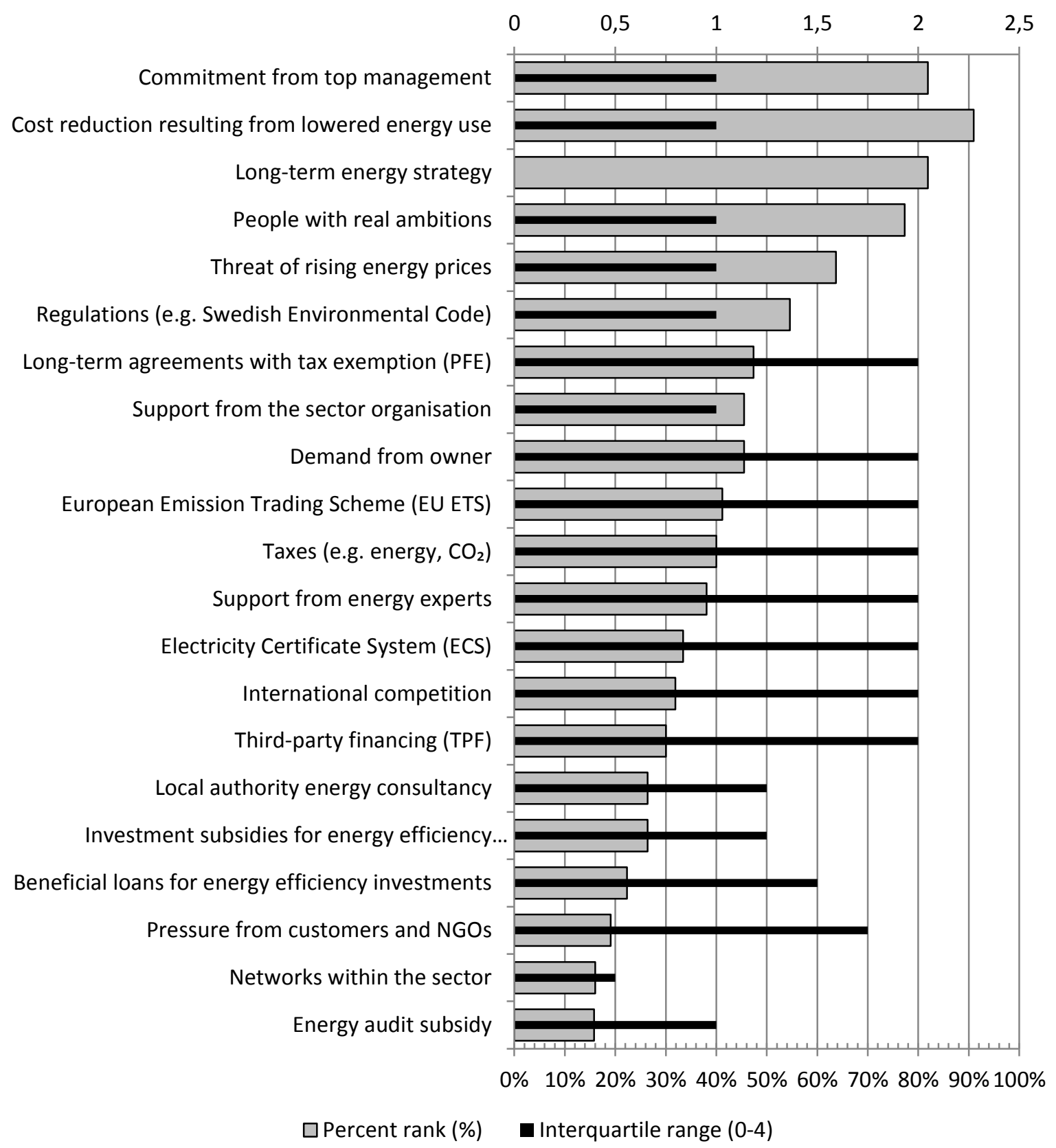

Figure 4: Drivers for the adoption of cost-effective ECM in the Swedish ISI ranked first after the mode and second after the percent rank. The percent rank displays the percentage of respondents that rated that barrier as important (4 on the Likert scale) or very important (5). The interquartile range (0-

4) indicates the dispersion of the responses and is calculated as the difference between the upper quartile $\mathrm{Q}_{.75}$ and the lower quartile $\mathrm{Q}_{.25}$.

When the drivers are categorised according to Table 6, it is noteworthy that the two most important actions have their origin within the company, i.e., in-house (see Figure 5), and thus can be stated to be related with energy management practices. In particular 
for economics-related drivers, the driving forces within the company are ranked on average two times higher than outside economics-related drivers. A similar connection can be found between internal and external information-related drivers. External information (e.g. support from energy experts) was ranked lowest but with the highest dispersion. A more detailed view shows that in particular downstream actors are in the need for external information (see Figure 6). For both origins, economic-related driver are ranked as highest. In Thollander et al. (2013), financial-related drivers, which can be compared to our economic category, were also ranked highest. They concluded that energy-intensive companies started to perceive energy efficiency as a very promising field that can increase their competitiveness. Remarkably, regulatory actions are considered of moderate importance which reflects the generally sceptical attitude of the firms regarding political interventions we experienced during the interviews.

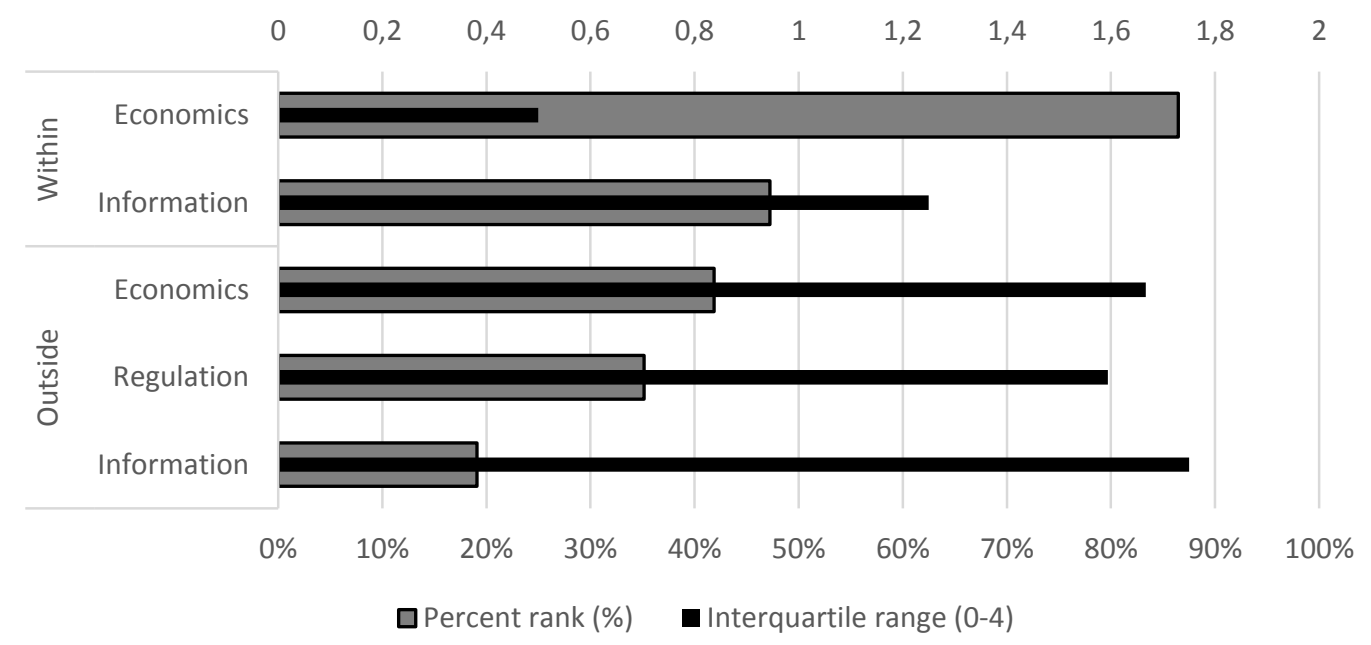

Figure 5: Drivers for the adoption of cost-effective ECM categorised according to origin and action (see Table 6). The drivers are ranked according to the percent rank (see Figure 4).

Similar to the barrier section, divergences between steel producers and downstream actors with a significance level of 0.05 are investigated. Here, it is revealing that policy measures like long-term agreements with tax exemption (PFE), taxes (e.g. electricity, 
energy, $\mathrm{CO}_{2}$, sulphur, $\mathrm{NO}_{x}$ ), Electricity Certificate System (ECS) were ranked higher by downstream actors than by steel producers (Mann-Whitney $\mathrm{U}_{\mathrm{PFE}}=56.5, \mathrm{U}_{\mathrm{Taxes}}=33, \mathrm{U}_{\mathrm{ECS}}$ $=70.5, \mathrm{n}_{\text {Downstream actor }}=14, \mathrm{n}_{\text {Steel producer }}=9, \mathrm{P}<0.05$ two-tailed). Similar differences among the categories could be identified for the drivers related to information with the origin from within the company (see Table 6) and for the driver support from energy experts $(\mathrm{U}=30.5)$ in particular (see Figure 6).

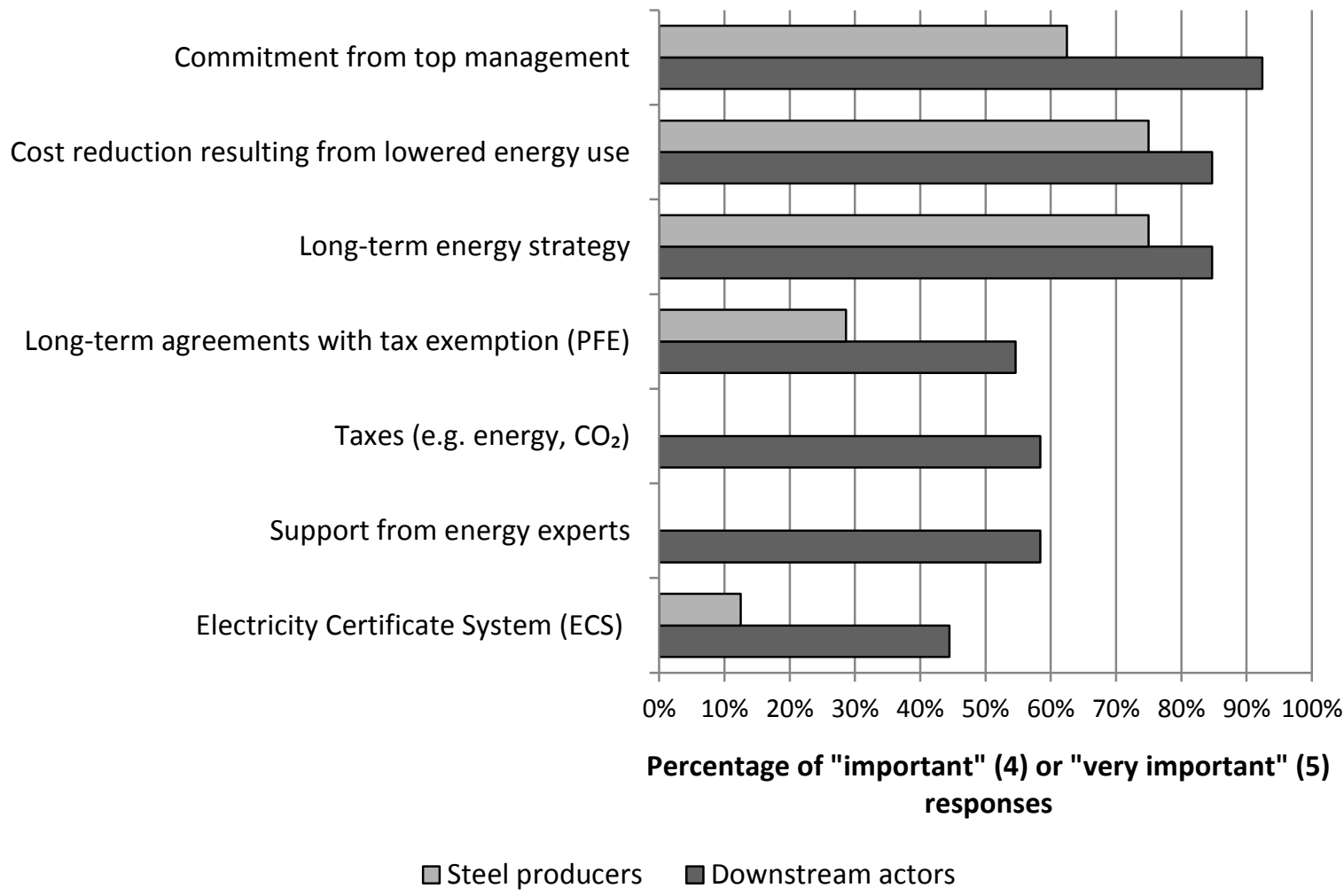

Figure 6: Responses on selected drivers for the adoption of cost-effective ECM in the Swedish ISI divided into the two groups steel producers and downstream actors.

\section{Energy management practices}

Recent studies like Backlund et al. (2012b) and Palm and Thollander (2010) remark that in the research into energy use and improved energy efficiency, researchers focus on the diffusion of cost-effective EC technologies and neglect that technology is part of the organisation as an integrated system. They point out that a combined approach of 
technology and energy management practices will in fact lead to higher EC potential. So

far only a few surveys have investigated actual energy management practices in manufacturing firms (see Table 7).

Table 7: Overview of selected surveys on the investigation of energy management practices in manufacturing firms

\begin{tabular}{|c|c|c|c|c|}
\hline Study & Sector & Area & $\begin{array}{l}\text { Categories and aspects for sound } \\
\text { energy management practices }\end{array}$ & Main findings \\
\hline $\begin{array}{l}\text { (Christoffers } \\
\text { en et al., } \\
2006)\end{array}$ & $\begin{array}{l}\text { Industrial } \\
\text { firms with } \\
\text { more than } 19 \\
\text { employees }\end{array}$ & Denmark & $\begin{array}{l}\text { A: Low degree of energy } \\
\text { management or no energy } \\
\text { management, } \\
\text { B: Relatively high degree of energy } \\
\text { management in general (e.g. mapping } \\
\text { of energy use, continuous energy } \\
\text { accounting), but low on the } \\
\text { organisational aspects (e.g. energy } \\
\text { policy, quantitative efficiency goals), } \\
\text { C: Relatively high degree of energy } \\
\text { management in general, as well as in } \\
\text { relation to the organisational aspects. }\end{array}$ & $\begin{array}{l}\text { With } \\
\text { minimum } \\
\text { requirements: } \\
3-14 \% \text { practise } \\
\text { energy } \\
\text { management }\end{array}$ \\
\hline $\begin{array}{l}\text { (Thollander } \\
\text { and } \\
\text { Ottosson, } \\
2010 \text { ) }\end{array}$ & $\begin{array}{l}\text { Foundry, pulp } \\
\text { and paper }\end{array}$ & Sweden & $\begin{array}{l}\text { First category: Pay-back criteria }>=2 \\
\text { years for energy efficiency } \\
\text { investments, energy strategy }>=3 \\
\text { years, sub-metering of energy costs. } \\
\text { Second category: Comply with two } \\
\text { requirements of the first category } \\
\text { Third category: Remaining } \\
\text { companies }\end{array}$ & $\begin{array}{l}40 \% \text { mills and } \\
25 \% \text { foundries } \\
\text { are successful } \\
\text { in energy } \\
\text { management }\end{array}$ \\
\hline $\begin{array}{l}\text { (Stenqvist et } \\
\text { al., 2011) }\end{array}$ & Pulp and paper & Sweden & $\begin{array}{l}\text { No categorisation, aspects include: } \\
\text { energy management coordinator, } \\
\text { management and staff commitment, } \\
\text { energy cost allocation, monitoring } \\
\text { and reporting, training }\end{array}$ & $\begin{array}{l}\text { Energy } \\
\text { management } \\
\text { practices } \\
\text { reduced } \\
\text { electricity } \\
\text { consumption } \\
\text { by } 3 \% \text { p. a. }\end{array}$ \\
\hline $\begin{array}{l}\text { (Ates and } \\
\text { Durakbasa, } \\
\text { 2012) }\end{array}$ & $\begin{array}{l}\text { Cement, paper } \\
\text { and pulp, ISI, } \\
\text { ceramics, } \\
\text { textile } \\
\text { industries }\end{array}$ & Turkey & $\begin{array}{l}\text { Companies who practice energy } \\
\text { management and companies who } \\
\text { don't (based on Christoffersen et al., } \\
\text { 2006). Aspects (e.g. energy strategy, } \\
\text { energy managers and their activities, } \\
\text { energy conservation targets, } \\
\text { knowledge on energy management) } \\
\text { are adapted from Christoffersen et al. } \\
\text { (2006). }\end{array}$ & $\begin{array}{l}\text { Degree of } \\
\text { energy } \\
\text { management } \\
\text { application is } \\
22 \%\end{array}$ \\
\hline $\begin{array}{l}\text { (Backlund et } \\
\text { al., 2012a) }\end{array}$ & $\begin{array}{l}\text { Selected non- } \\
\text { energy and } \\
\text { energy- } \\
\text { intensive } \\
\text { industries }\end{array}$ & $\begin{array}{l}\text { Gävlebor } \\
\mathrm{g} \\
\text { County, } \\
\text { Sweden }\end{array}$ & $\begin{array}{l}\text { Companies who have participated in } \\
\text { PFE (see section 4) or conducted an } \\
\text { energy audit in the last three years } \\
\text { and companies who haven't. Aspects } \\
\text { include top management support, } \\
\text { long-term energy strategy, energy } \\
\text { manager with operational } \\
\text { responsibility, sub-metering. }\end{array}$ & $\begin{array}{l}\text { Firms who } \\
\text { participate in } \\
\text { PFE have } \\
\text { better energy } \\
\text { management } \\
\text { practices (e.g. } \\
70 \% \text { fulltime } \\
\text { energy }\end{array}$ \\
\hline
\end{tabular}


(Sivill et al., Three energy- Finland No categorisation, aspects include: 2013) intensive sectors feasibility, organisational systems, awareness monitoring and development of implementation
Energy performance measurement is the third development priority in energy management, behind resource and commitment issues.

Although standards for energy management like ISO 50001 are available, results of the surveys and theoretical contributions like Backlund et al. (2012b) remark that how companies define energy management depends on the size and type of industry. In order to ensure consistency with existing energy management standards, we used the Energy Management Matrix by Carbon Trust (2011) to assess the energy management practices of the Swedish ISI. We complemented the matrix with important success factors for energy management practices - long-term energy strategy, top-management commitment and sub-metering - identified by previous research (see Thollander and Ottosson, 2010; Trygg et al., 2010; Worrell et al., 2010). We adapted the Carbon Trust's matrix and divided the factors into five categories: Policy, Organization, Information systems, Awareness and Investment. The company receives points for every factor they respected in their energy management practices. The total sum for each category is put in relation to the best case (see Figure 7). In this way, we receive a more granular understanding of the actual level of energy management in the Swedish ISI than by using two or three categories (see Table 7). The success factors for each category, including their points, are presented in the following chapters. 


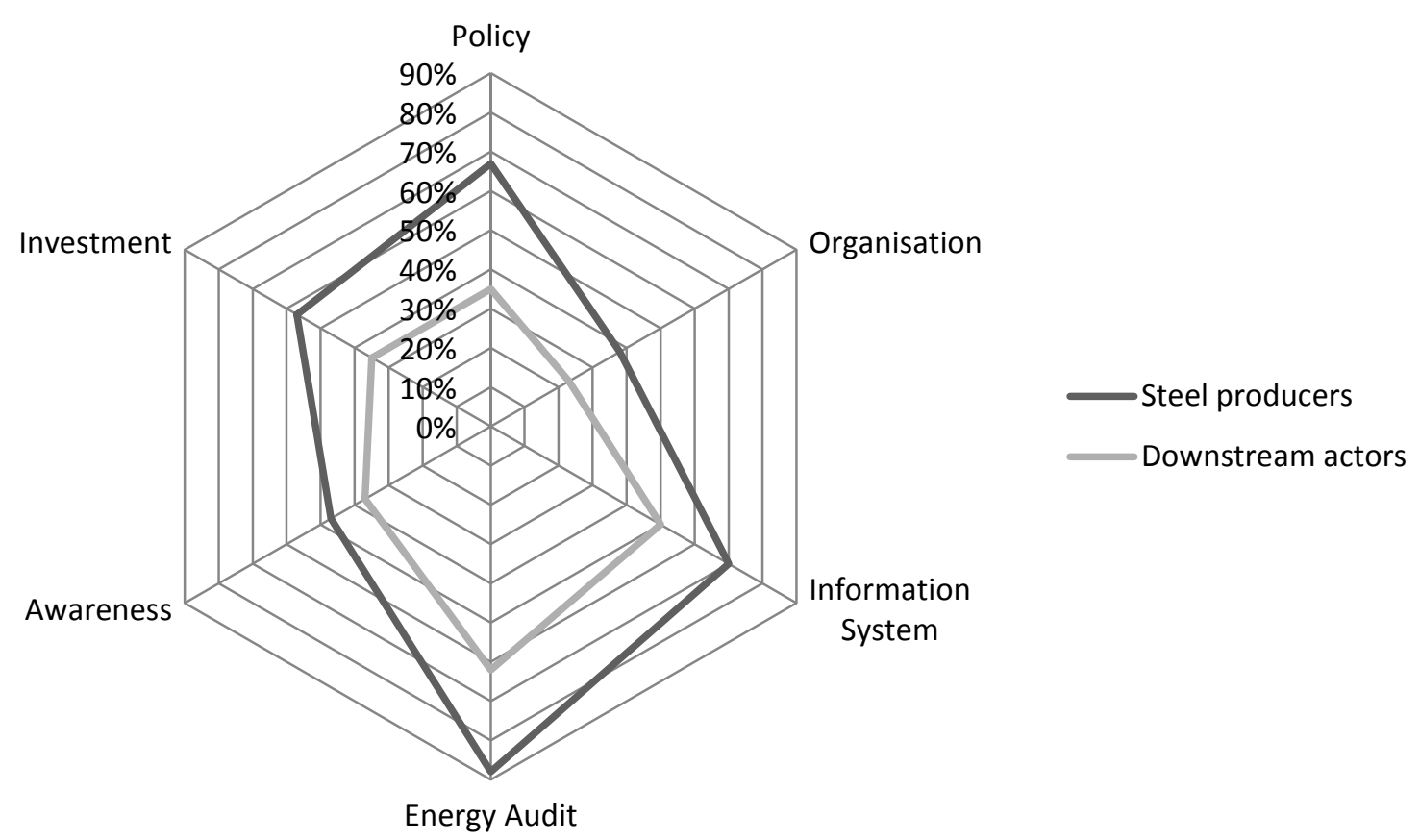

Figure 7: The soundness of six energy management categories displayed in a spider web chart for steel producers and downstream actors. The company receives points for every factor they included in their energy management practices. The total sum for each category is put in relation to the best case.

\subsection{Policy}

According to the results of the driver analysis and previous studies, having a longterm energy strategy is crucial for the adoption of cost-effective ECM (Thollander and Ottosson, 2010; Trygg et al., 2010; Rohdin et al., 2007). For the quantification of the soundness of the policy-related practices, a long-term energy strategy respecting a time horizon of more than three years is weighted twice as much as a time horizon between one and three years while companies with no policy or unwritten set of goals received no points (see Figure 8). Not surprisingly, more steel producers have a proper energy strategy in place than downstream actors. However, the seven companies with a longterm energy strategy longer than three years - including the two downstream actors have the largest number of employees of all participating companies, indicating that the soundness of this category is more likely correlated with the size of the company rather than with its energy intensity. 


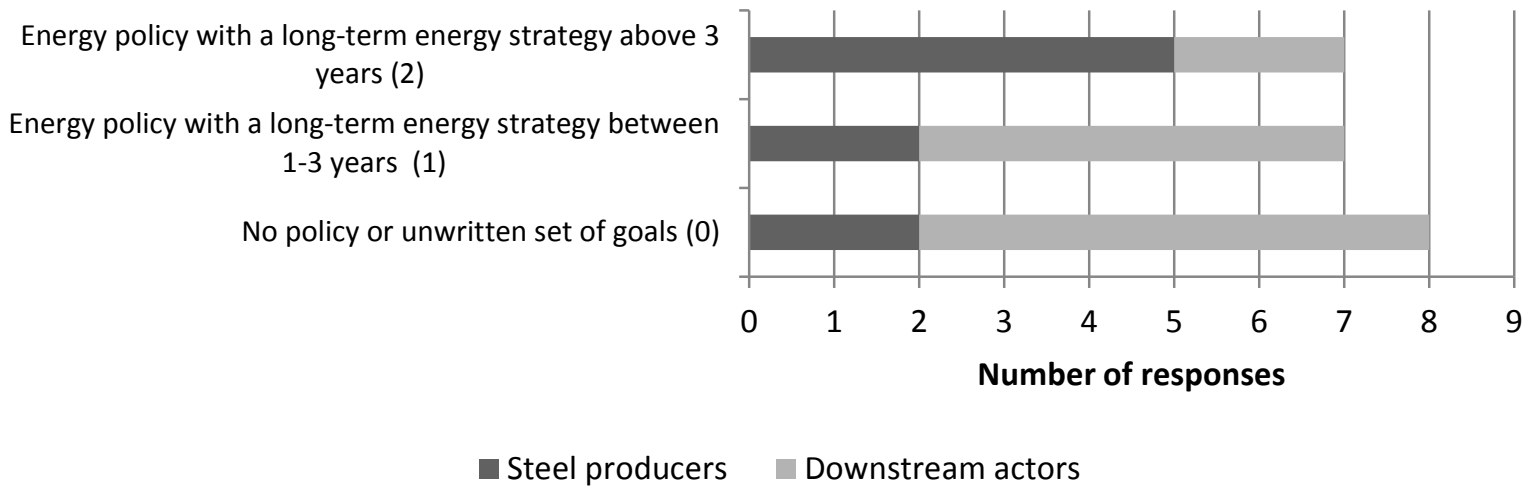

Figure 8: Responses to the question how a long-term energy strategy is treated in the company's energy policy. The number in brackets displays the points for the energy management practice (see

Figure 7).

\subsection{Organisation}

An important organisation-related success factor for energy management is the employment of a full-time energy manager who is integrated into the management structure, fully responsible for energy consumption and equipped with the necessary authority for energy efficiency investments (Sandberg and Söderström, 2003). Only one steel producer and one downstream actor fully complied with these requirements. Five steel producers and eight downstream actors employed a part-time energy manager. The remainder had no energy manager in place. Similar to the policy part, the soundness of the organisation-related energy management practices is quantified, whereby having a full-time energy manager in place was weighted twice as important as having a part-time energy manager.

\subsection{Information system and initial energy audit}

Allocating energy cost at sub level and a thorough initial energy audit are requirements for sound energy management. The results show that most companies allocate their energy consumption per tonne (65\% of the participating companies) while only $26 \%$ use sub-metering. None of the participating companies allocate the energy cost 
per square meter or per employee. When it comes to the type of energy measured, all 23 companies meter electricity, 16 fuel and 14 steam and hot water and there is no significant difference between the two groups (see Figure 9). Furthermore, $89 \%$ of the steel producers and $62 \%$ of the downstream actors had conducted energy audits. The percentages for the soundness of the information systems are calculated as follows: $S u b$ metering is weighted with a factor of three, daily metering with a factor of two and the remainder, i.e., allocation per tonne, metering electricity, fuel steam and hot water, monthly-weekly metering, monitoring trends, with a factor of one.

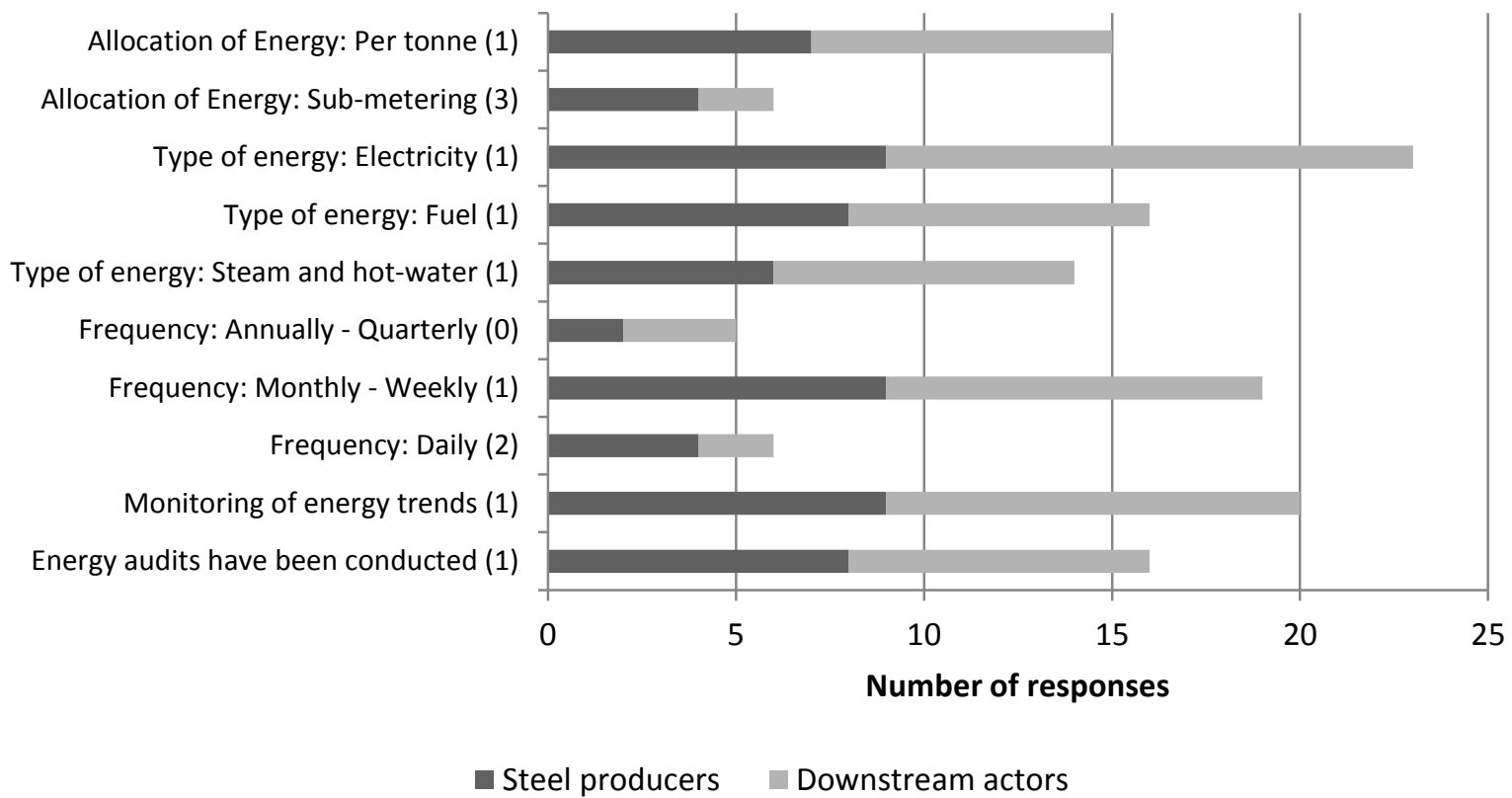

Figure 9: Responses to the questions regarding the information system as part of energy management: allocation of energy, types of energy, frequency and monitoring of energy trends. It was further asked if the company had conducted an initial energy audit which is seen as an enabler for energy efficiency

(see Sandberg and Söderström, 2003). The number in brackets indicates how the responses are weighted for the total soundness calculation (see Figure 7).

\subsection{Awareness}

Advertising the value of energy efficiency to employees on a regular basis is stated by Carbon Trust's energy management matrix as an important aspect and was included in the questionnaire. The results show that the majority of the downstream actors $(57 \%)$ 
do not promote energy efficiency and do not train their personnel (see Figure 10). At least six out of nine steel producers and five out of 13 downstream actors have occasional awareness campaigns and personnel trainings. Only $13 \%$ of the companies train and promote energy efficiency on a regular basis. The soundness has been quantified similar to the policy and organisation category and is shown in Figure 7. Besides organisational factors, awareness practices have the second largest improvement potential, in particular for the downstream actors.

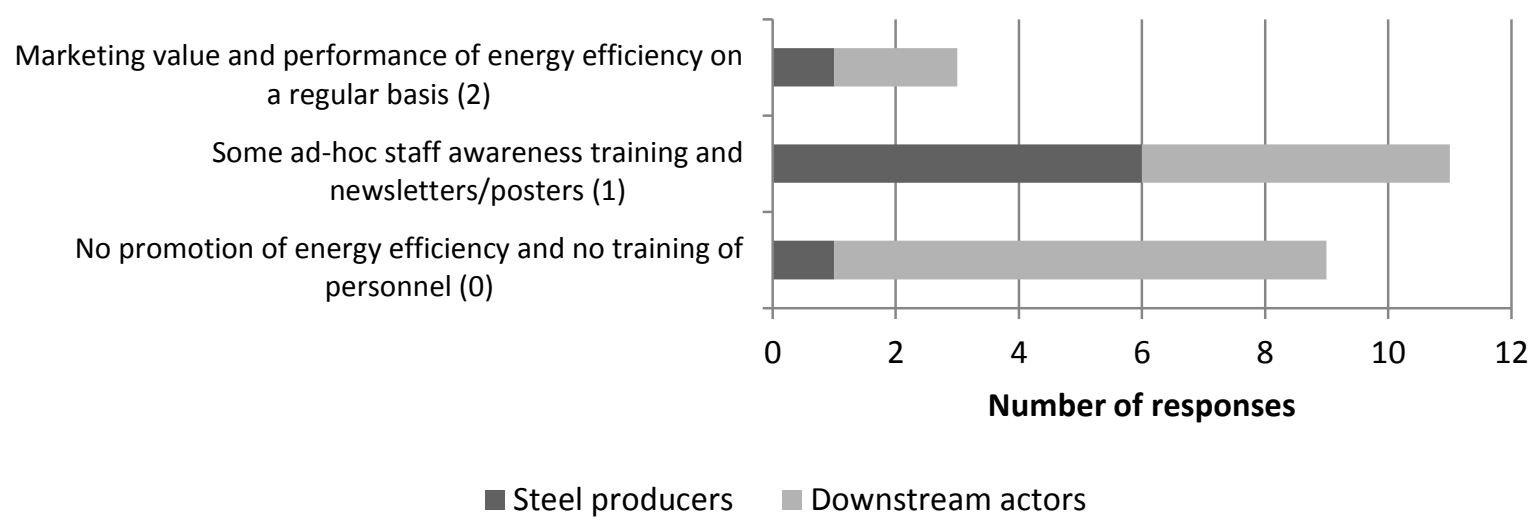

Figure 10: Responses on how energy efficiency is advertised to the employees. The number in brackets indicates how the responses is weighted for the total soundness calculation (see Figure 7).

\subsection{Investment criteria}

Considering investments in ECM with a payback time of more than three years was identified in the literature as an important prerequisite to improve energy efficiency (Thollander and Ottosson, 2010; DEA, 2002). Among downstream actors $77 \%$ and 100\% of the steel producers use payback time for profitability calculations, but only four companies consider investments with payback times longer than three years (see Figure 11). 


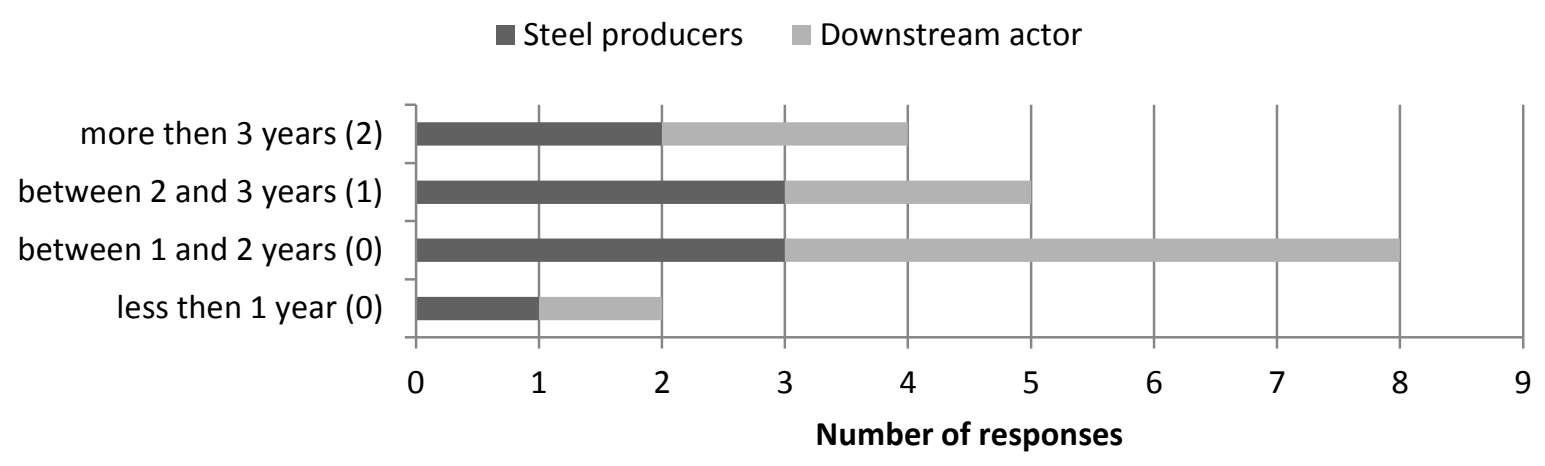

Figure 11: Maximum payback time for investments in EC technologies. The number in brackets indicates the points for the total soundness calculation (see Figure 7).

Additionally, the internal rate of return (IRR) is used by three companies with minimum return rates of $25 \%, 15 \%$ and $5 \%$. Only one steel producer also calculates the net present value $(N P V)$ which - as well as the IRR - is a more appropriate approach compared to the payback time to evaluate the profitability of investments. For the quantification of the soundness of the investment practices, only the payback times were considered and weighted similar to the policy-related practices (see section 4.1).

\section{ESCOs}

Energy Service Companies (ESCOs) have been identified as important change agents to overcome barriers to energy efficiency and to achieve sustainable economic development (cf. EC 12/11/2012; Bernstein et al., 2007). Although both the EU and the Swedish government have acknowledged the ESCO concept by directly taking it into account in the Directive 2012/27/EU and Sweden's Second National Energy Efficiency Action Plan (see Swedish Government 2011), Backlund and Thollander (2011), Soroye and Nilsson (2010) and Bertoldi et al. (2006) identified only moderate ESCO activities and considerable growth potential of the ESCO market in Sweden. While most the studies analysed the ESCO market situation and barriers for companies to consult ESCOs, companies' experiences with ESCOs have only been modestly reflected in the literature 
(see Table 8). In our study, we asked the participants in the questionnaire and in the follow-up telephone interviews what type of ESCOs they had experience with, what service they requested, and what the barriers are - from a client's perspective - to consulting ESCOs.

Table 8: Selected studies on ESCOs

\begin{tabular}{|c|c|c|c|}
\hline Study & Type/Focus & Area & Main findings \\
\hline $\begin{array}{l}\text { (Painuly et al., } \\
\text { 2003) }\end{array}$ & $\begin{array}{l}\text { Barriers to } \\
\text { ESCOs growth } \\
\text { and removal } \\
\text { measures }\end{array}$ & $\begin{array}{l}\text { Non- } \\
\text { OECD }\end{array}$ & $\begin{array}{l}\text { Key driver for ESCO growth: Promotion of } \\
\text { ESCOs by active involvement of } \\
\text { governments as a customer, information } \\
\text { provider, and policy maker. }\end{array}$ \\
\hline $\begin{array}{l}\text { (Bertoldi et al., } \\
\text { 2006) }\end{array}$ & $\begin{array}{l}\text { ESCO market } \\
\text { analysis }\end{array}$ & EU & $\begin{array}{l}\text { ESCO activities various from top countries } \\
\text { (Germany, Austria, UK, Spain, Hungary), } \\
\text { middle range countries (France, Sweden, } \\
\text { Czech Republic, Italy) and to other } \\
\text { countries with low ESCO activity. }\end{array}$ \\
\hline (Da-li, 2009) & $\begin{array}{l}\text { Barriers to } \\
\text { ESCOs growth } \\
\text { and removal } \\
\text { measures }\end{array}$ & China & $\begin{array}{l}\text { First measure to overcome barriers is to } \\
\text { build up awareness of EC and promote } \\
\text { energy performance contracting by ESCOs }\end{array}$ \\
\hline $\begin{array}{l}\text { (Satchwell et al., } \\
\text { 2010) }\end{array}$ & $\begin{array}{l}\text { ESCOs market } \\
\text { analysis }\end{array}$ & USA & $\begin{array}{l}\text { Key driver for ESCO growth: increase in } \\
\text { funding local government energy efficiency } \\
\text { programs, customer interest to mitigate } \\
\text { higher utility bills, environmental concerns. }\end{array}$ \\
\hline $\begin{array}{l}\text { (Soroye and } \\
\text { Nilsson, 2010) }\end{array}$ & $\begin{array}{l}\text { ESCO market } \\
\text { analysis }\end{array}$ & Sweden & $\begin{array}{l}\text { Key driver for ESCO growth: rising energy } \\
\text { prices, climate change concerns, favourable } \\
\text { policy environment, } \\
\text { Mutual trust between companies and } \\
\text { customers has grown, } \\
\text { third-party financing has played a } \\
\text { surprisingly unimportant role }\end{array}$ \\
\hline $\begin{array}{l}\text { (Backlund and } \\
\text { Thollander, } \\
\text { 2011) }\end{array}$ & $\begin{array}{l}\text { ESCO (towards } \\
\text { SMEs) market } \\
\text { analysis }\end{array}$ & Sweden & $\begin{array}{l}\text { ESCOs' main advantage: improving energy } \\
\text { efficiency in generic technologies due to } \\
\text { economics of scale } \\
\text { ESCOs' disadvantages in contrast to in- } \\
\text { house consulting: increased transaction } \\
\text { costs }\end{array}$ \\
\hline $\begin{array}{l}\text { (Backlund et al., } \\
\text { 2012a) }\end{array}$ & $\begin{array}{l}\text { Energy } \\
\text { management } \\
\text { practices } \\
\text { including energy } \\
\text { services }\end{array}$ & $\begin{array}{l}\text { Gävleborg } \\
\text { County, } \\
\text { Sweden }\end{array}$ & $\begin{array}{l}\text { Main consulted energy services are } \\
\text { consultation, installation and operation and } \\
\text { maintenance of support processes. }\end{array}$ \\
\hline
\end{tabular}




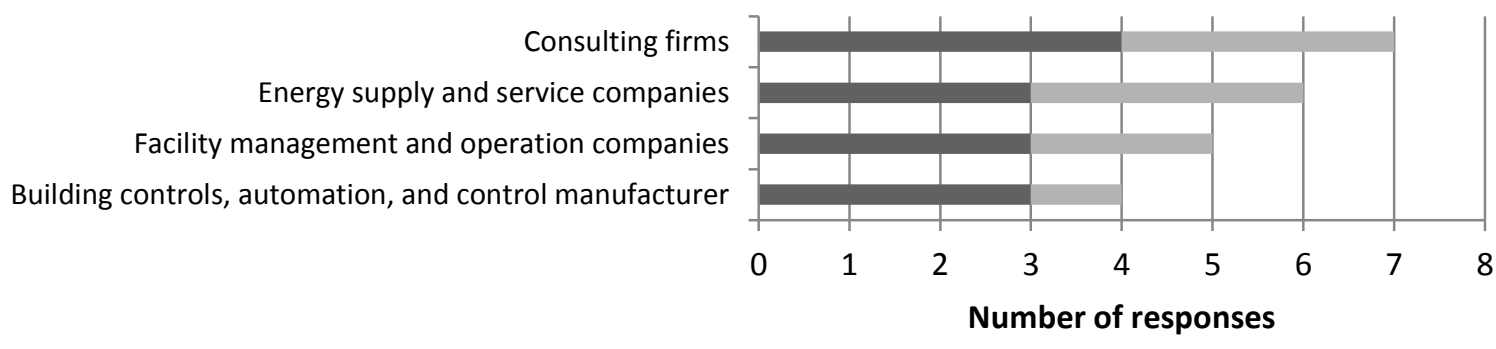

- Steel producers Downstream actors

Figure 12: Types of ESCOs consulted by steel producers and downstream actors.

The results of our study show that 13 of 23 participating companies have consulted ESCOs so far. These were mainly consulting and energy supply and service companies (see Figure 12). The majority of the hereby requested services were project managementrelated, i.e., identification and appraisal, technical design and implementation (see Figure 13). Furthermore, only four companies used third-party financing (TPF) for the investment in EC technologies in the last five years. This low figure does not match the proactive role of TPF as stated by the directive on energy efficiency by the European Commission (see EC 12/11/2012) but is in line with findings by Soroye and Nilsson (2010).

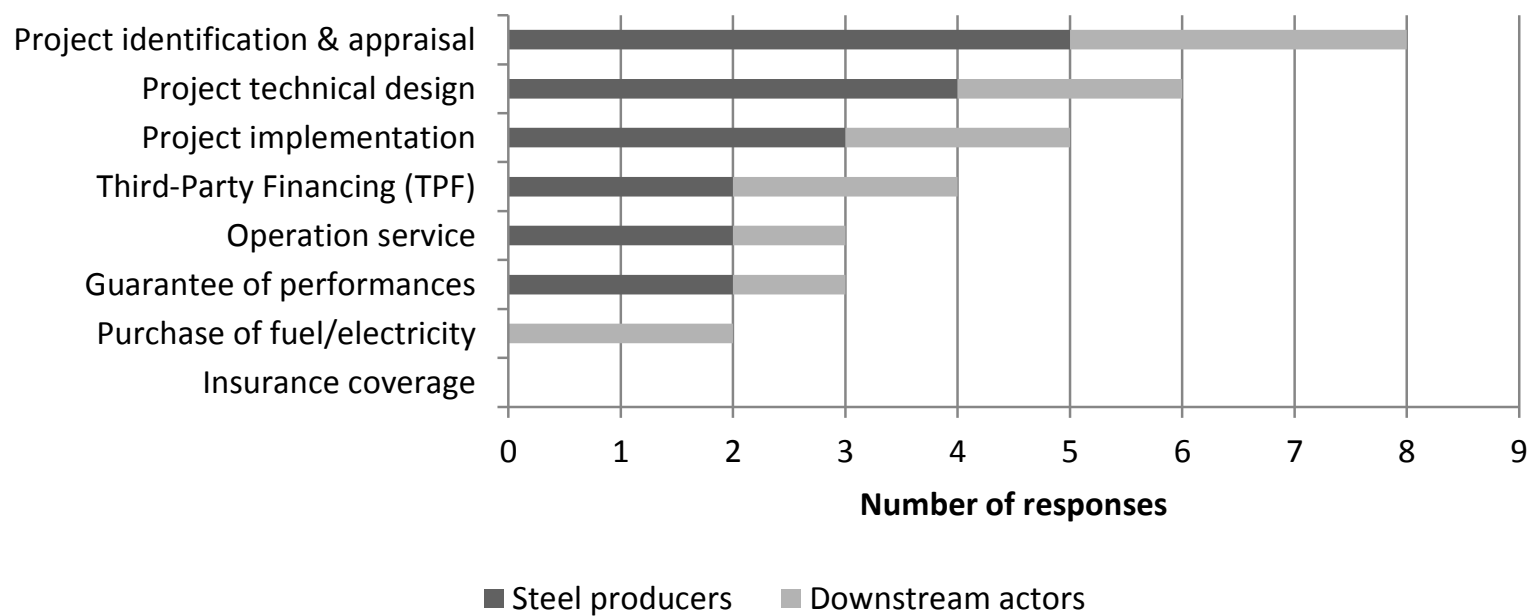

Figure 13: Requested energy services by steel producers and downstream actors. 
The experiences of the ISI with ESCOs show great variation with regard to the requested service. While the ISI has had good, long-lasting experience with ESCOs in the field of energy supply and facility management, the steel companies' feedback in terms of consultant services was not promising. In the follow-up telephone interviews, steel producers stated that consultants showed a lack of knowledge about steel production processes and the ISI in general. Accordingly, the barrier lack of technical competence / trained professionals (energy engineers) was ranked as most important by steel producers (see Figure 14). It was revealing that companies with a small firm size - a majority of them downstream actors - had no knowledge about the services provided by ESCOs. This lack of knowledge is reflected by the responses on the barriers to consulting ESCOs. Based on the rating of the lack of actors barrier and the conversations with the companies, we can conclude that the Swedish market for ESCOs has not gained enough traction to fulfil the proactive role the European Commission has attributed to them.

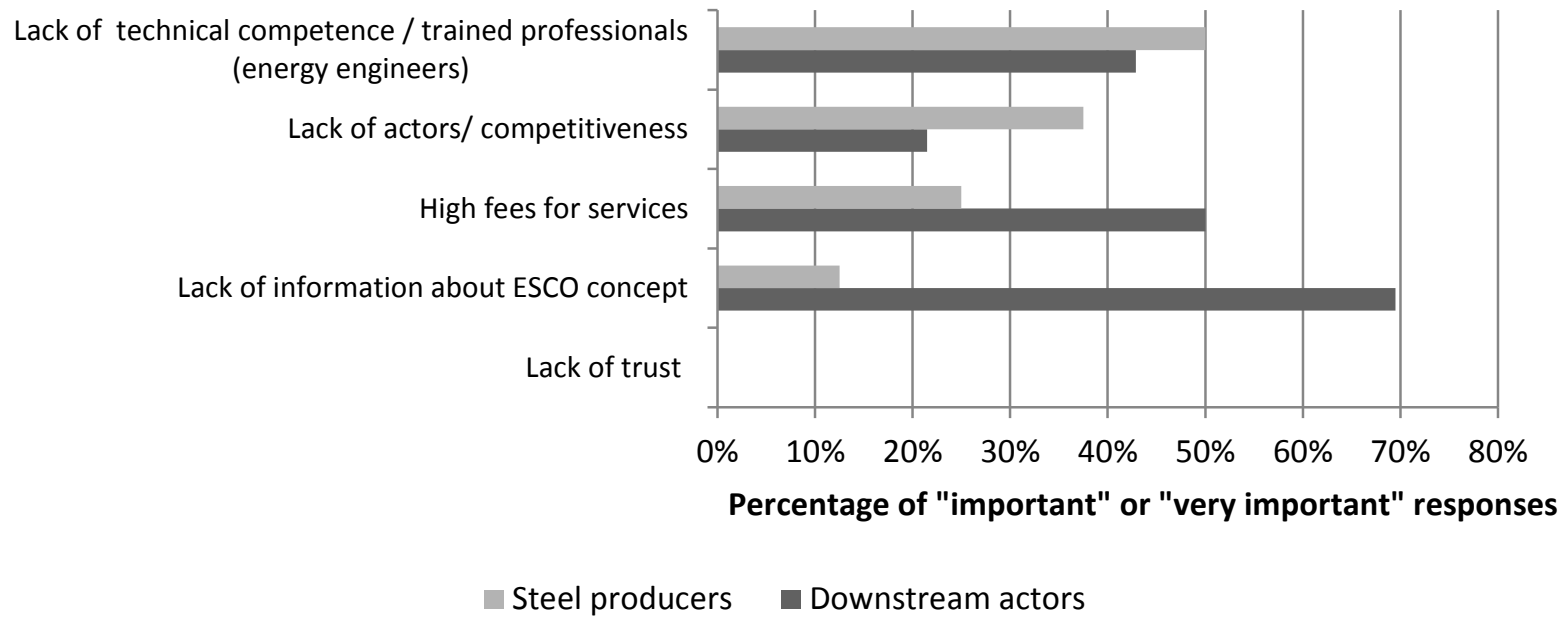

Figure 14: Barriers to consult ESCOs ranked according to their percent rank.

\section{Energy conservation potentials}

In the questionnaire, the participants were directly asked to state the technoeconomic EC potential that can be achieved by adopting all available cost-effective 
technologies (see Jaffe and Stavins, 1994). Hereby, the quality of the estimation depends to a large extent on the technical and economical knowledge of the participants. Before sending the questionnaire, we checked with the point of contact whether he is able to give a sound estimate to this answer. Further, participants were asked instead to give no response if they had any doubts about their estimate. In this context, two downstream actors left the respective field blank. The estimated weighted average of the EC potential for solely adopting cost-effective EC technologies was $7.3 \%$ of the total energy use of the responding steel companies. It needs to be noted that the actual EC technologies, due to their heterogeneity and complexity, are not the focus of this study. We recommend consulting Brunke and Blesl (2014) and Johansson and Söderström (2011) for information on ECM in the production of iron and steel.

When the assessed potential is compared to the respective energy intensity, i.e., the ratio of total energy consumption to the company's total turnover per year, it was revealing that companies with a higher energy intensity generally assessed a lower EC potential. Accordingly, the weighted average techno-economic EC potential of the steel producers is lower at $6.7 \%$ than the weighted average potential of downstream actors at $12.9 \%$ (see Figure 15). It is notable that one downstream actor stated a techno-economic EC potential of 50\%. In the follow-up interviews the respective respondent stated that "[they] are not very good with energy" and use technology that is several decades old. This observation was from further investigations excluded. Furthermore, the respective fields in the questionnaire were not restricted to numbers so the participants could populate any kind of text. Here, it was revealing that the majority of the downstream actors stated ranges like "10-20\%" while steel producers mainly gave precise numbers. The follow-up telephone conversations revealed that most of the steel producers have 
conducted a thorough energy audit recently and could state accurate numbers based on the outcome of these audits.

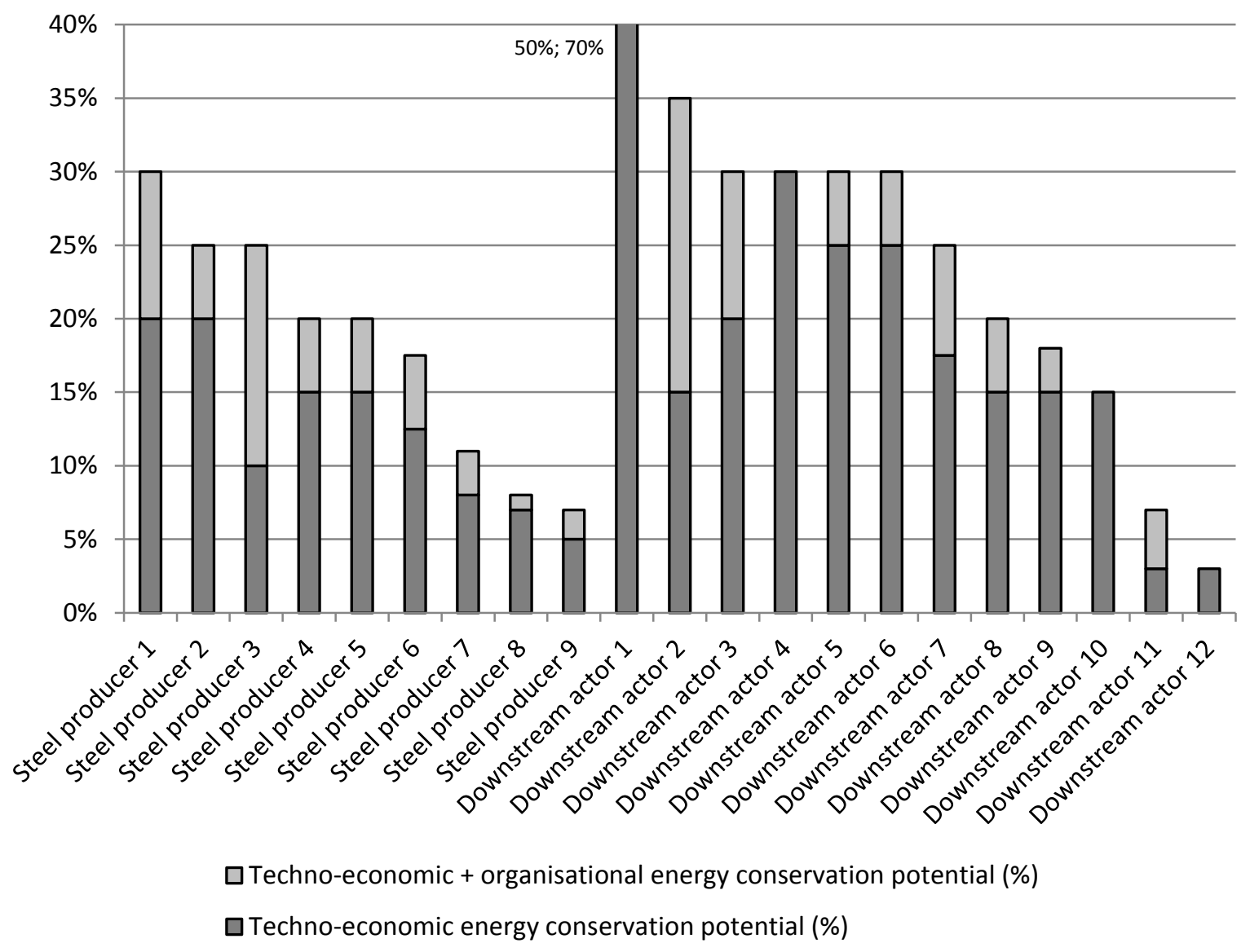

Figure 15: The individual techno-economic and organisational EC potential in percent of the respective company's energy use. While the techno-economic potential represents the adoption of all available cost-effective EC technologies, the organisational EC potential can be achieved through sound energy management practices (see Backlund et al., 2012b).

We discussed the integrated system approach of Backlund et al. (2012b) and Palm and Thollander (2010) - the adoption of cost-effective ECM in combination with sound energy management practices will lead to an higher potential (see section 4) - in the follow-up interviews which was well accepted by the interviewees. Among other things, it was argued by the participants that sound energy management ensures that the priorities and potential EC options will be discussed on a high organisational level which avoids sub-optimisation. It would furthermore give a long-term view of the whole site rather 
than sub-optimising single areas with a short-term perspective. Accordingly, the EC potential of the combined approach was assessed in the questionnaire to be $2.4 \%$ higher than the techno-economic potential. The weighted average total potential of $9.7 \%$ is near the $12 \%$ of the Backlund et al. (2012a) study in the Swedish county of Gävleborg with a similar understanding of the addressed potentials. However, as results from this paper show that EC potential is related to energy intensity, and seems to be considerably lower for highly energy-intensive companies, EC potential figures should be treated with caution.

\section{Concluding discussion}

Our study investigates four aspects that are associated with the adoption of energy cost-effective ECM in the Swedish ISI: barriers, drivers, energy management practices and energy services. Twenty-three of 46 identified members of the Swedish steel producers' association participated in our study, which represents $80 \%$ of the sector's total turnover. Our study stands out from previous contributions, because it covers these four aspects in the same empirical investigation. In this way, the linkages between the aspects can be investigated, which provides a more holistic view of the subject than an isolated investigation. Accordingly, the conclusions based on the connections and interactions between the particular aspects are discussed and concluded in this chapter, first for the whole sample size and then for steel producers and downstream actors separately.

7.1 Whole sample size

The most important perceived barriers, i.e., technical risks, limited access to capital and other priorities for financial investment, can be related to the economic area in the Cagno et al. (2013) taxonomy. This conclusion is within the corridor of results of other 
studies (see Table 3) and reflects to some degree the continuing effects of the global financial crisis on the highly export-oriented Swedish ISI. The economic restrictions are mirrored by the high restrictions on the profitability of EC investments. Only four of 23 companies invest in ECM with payback time of more than three years. On the other side, external drivers that address the economic issue, e.g. TPF, energy audit subsidies and investment subsides for energy efficiency technologies, were rated as being of only moderate importance for participants. In particular TPF, which is advised by policymakers as a market-oriented approach to overcome firms' economic restrictions, was hardly requested as an energy service. In line with Soroye and Nilsson (2010), the interviewees stated that hardly any company offers TPF services. Further research on actions to raise the attractiveness for ESCOs to provide and for companies to request TPF services is suggested. Moreover, the high ranking of lack of actors indicates that policy actions are needed to expand the size and attractiveness of the Swedish ESCO market.

According to the participants, internal economic-related drivers, e.g. cost reduction resulting from lowered energy use, are twice as important for the adoption of costeffective ECM than the abovementioned external drivers. This means that according to the companies themselves, the most effective point of leverage to improve energy efficiency is within the company. Furthermore, half the firms assessed behavioural barriers like insufficient top management support to be important barriers. The investigation of the energy management practices showed that steel companies are actively engaged in the topic, but need to raise the value and awareness of energy efficiency within the company. Energy management systems are an important tool to establish a sustainable mindset to improve energy efficiency. Studies like Backlund et al. (2012a) showed that long-term agreements such as the Swedish PFE (Program for Energy Efficiency in energy-intensive industry) can facilitate such a mindset by demanding that 
companies, among other things, implement an energy management system in order to get a $100 \%$ electricity tax refund. The high ranking of the respective driver, the positive feedback of the interviewees, along with the findings of Backlund et al. (2012a) and Thollander and Ottosson (2008) indicate that the PFE is a promising concept which can help in overcoming barriers to the adoption of ECM in other countries.

\subsection{Steel producers}

The production processes of steel producers are in comparison to downstream actors more complex and integrated. Accordingly, technical risks are the most important barrier for steel producers to the adoption of cost-effective EC technologies. The focus of Swedish steel producers on niche products resulted in an even higher degree of specialisation of the already sector-specific production processes. Thus, external consultants need much time to become comfortable with the plant design which is one aspect of the steel producers to perceive the lack of technical competence as the crucial barrier to request energy services. As a consequence of failed projects, we experienced a lack of trust from steel producers towards the ESCO concept. The low rating of limited access to capital barrier, the considerable turnover of 7,000 million $\mathrm{SEK}_{2012}$ on average and the low rating of the TPF driver show that financial services like TPF are not of interest to steel companies. However, some steel producers had good and long-lasting energy services for support processes like energy distribution and supply. We conclude that the concept of ESCOs is not equally suitable for all sectors and suggest ECSO in the case of process industries to focus instead on support processes.

Steel producers stated further a remarkably lower techno-economic and organisational EC potential compared to downstream actors. Provided that a lower potential is achieved because more cost-effective ECM had been adopted, the reasons are manifold: First of all, steel producers rated the lack of technical skills and lack of 
information about allocation of energy costs barriers as of low importance. We see one reason for this in the employment of an energy manager who deals with the company's energy efficiency on a regular basis. Another important reason is that eight of nine steel producers had recently conducted energy audits, and indicated a profound understanding of their EC options. These two facts are often referred to as the basic requirements for energy management and steel producers indeed showed a more profound energy management than downstream actors. Another reason for the low techno-economic EC potential is profitability. Profitability depends in case of ECM on several factors: capital and operation expenditures, economic lifetime, specific EC, energy prices, and the profitability method and criteria. Due to the high energy intensity of steel producers and the fact that potential ECM for the steel production process have high capital expenditures (cf. Brunke and Blesl, 2014), the energy cost reduction of ECM for steel producers is higher than for downstream actors. However, the steel producers' preference for short payback times limits the profitability of investment in ECM. Thus, policies that promote certified energy management systems and long cycles between policy changes, so that companies can make use of the capital-intensive long-term investments, are suggested to address the energy efficiency gap in the ISI of Sweden.

\subsection{Downstream actors}

In contrast to steel producers, downstream actors stated on average a considerably higher techno-economic and organisational EC potential. We give three reasons for this: First of all, downstream actors are - in comparison to steel producers - more limited in resources. The turnover of downstream actors is 14 times lower (median 575 million SEK 2012 ) making it difficult to acquire the necessary funds for investments in ECM as $77 \%$ of the downstream actors see limited access to capital as an important or very important barrier. Accordingly, downstream actors are more sensitive to market-based 
instruments as they rated the importance of policy-related drivers such as taxes (e.g. electricity, energy, $\mathrm{CO}_{2}$, sulphur, $\mathrm{NO}_{2}$ ) and Electricity Certificate Systems (ECS) higher than steel producers. We see the lack of knowledge regarding ECM as the second reason as only downstream actors rated the lack of technical skills barrier and the detailed support from energy experts (help desk) driver as important. Plus, only $62 \%$ of the downstream actors had performed an initial first-time energy audit. We see the third reason in the lack of energy management practices - $40 \%$ total soundness compared to $61 \%$ for steel producers - in particular in the categories: organisation, investment and policy. Accordingly, downstream actors rated energy management-related barriers and drivers higher. In contrast to steel producers, the different services of ESCOs harmonise with the needs of downstream actors. TPF for ECM investments addresses the identified capital issue. The production processes of downstream actors are less complex and more homogenous so that the consultation services (e.g. project identification \& appraisal) fit into the identified knowledge gap. Regarding energy management practices, results showed that the soundness is correlated with the numbers of employees. In order to respect the lower company size (median of 160 employees), we suggest that downstream actors appoint a high-level manager as part-time responsible for energy management. This manager could be supported on a regular basis by ESCOs so that comprehensive energy management is ensured. This concept, however, will not comply with existing standards for energy management systems which need to be accounted for in political incentives for firms to practice improved energy management (see Christoffersen et al., 2006). Regarding the downstream actors' lack of knowledge about ESCO services and the high concern of costs for energy services, we suggest that ESCOs start advertising their services towards downstream actors with transparent pricing.

\section{Acknowledgements}


The authors warmly thank the respondents at the studied plants for giving freely of their time and attention to answer the questions, and the anonymous reviewers for their good input and constructive suggestions.

\section{References}

Anderson, S.T., Newell, R.G., 2004. Information programs for technology adoption: the case of energy-efficiency audits. Resour. Energy Econ. 26, 27-50.

Ates, S.A., Durakbasa, N.M., 2012. Evaluation of corporate energy management practices of energy intensive industries in Turkey. Energy 45, 81-91.

Backlund, S., Broberg, S., Ottosson, M., Thollander, P., 2012a. Energy efficiency potentials and energy management practices in Swedish firms, in: ECEEE Summer Study on Energy Efficiency in Industry, Conference proceedings; 11 - 14 September 2012, Arnhem, Netherlands, pp. 669-677.

Backlund, S., Thollander, P., Palm, J., Ottosson, M., 2012b. Extending the energy efficiency gap. Energy Policy 51, 392-396.

Backlund, S., Thollander, P., 2011. The energy-service gap: What does it mean?, in: Lindström, T. (Ed.), Energy efficiency first: the foundation of a low-carbon society. ECEEE 2011 Summer Study; Conference proceedings; 6 - 11 June 2011, Belambra Presqu'île de Giens, France. ECEEE, Stockholm.

Bernstein, L.; Roy, J.; Delhotal, K. C.; Harnisch, J.; Matsuhashi, R.; Price, L. et al. (Eds.) (2007): Industry. In Climate Change 2007: Mitigation. Contribution of Working Group III to the Fourth Assessment Report of the Intergovernmental Panel. Cambridge, UK/New York, NY: Cambridge University Press.

Bertoldi, P., Rezessy, S., Vine, E., 2006. Energy service companies in European countries: Current status and a strategy to foster their development. Energy Policy 34, 1818-1832.

Blass, V., Corbett, C.J., Delmas, M.A., Muthulingam, S., 2014. Top management and the adoption of energy efficiency practices: Evidence from small and medium-sized manufacturing firms in the US. Energy 65, 560-571.

Brunke, J.-C., Blesl, M., 2014. A plant-specific bottom-up approach for assessing the costeffective EC potential and its ability to compensate rising energy-related costs in the German iron and steel industry. Energy Policy, 431-446.

Bryman, A., Becker, S., Sempik, J., 2008. Quality Criteria for Quantitative, Qualitative and Mixed Methods Research: A View from Social Policy. Int. J. Soc. Res. Methodol. 11, 261-276.

Burgess, T.F., 2001. A general introduction to the design of questionnaires for survey research, Leeds, UK.

Cagno, E., Trianni, A., 2013. Exploring drivers for energy efficiency within small- and medium-sized enterprises: First evidences from Italian manufacturing enterprises. Applied Energy 104, 276-285.

Cagno, E., Worrell, E., Trianni, A., Pugliese, G., 2013. A novel approach for barriers to industrial energy efficiency. Renew. Sustain. Energy Rev. 19, 290-308.

Carbon Trust, 2011. Energy management. A comprehensive guide to controlling energy use, UK. http://www.carbontrust.com/media/13187/ctg054_energy_management.pdf. Accessed August 16, 2013. 
Cassell, C. (2004): Essential Guide to Qualitative Methods in Organizational Research. London: Sage Publications.

Christoffersen, L.B., Larsen, A., Togeby, M., 2006. Empirical analysis of energy management in Danish industry. J. Clean. Prod. 14, 516-526.

Currás, T.A., 2010. Barriers to investment in energy saving technologies. Case study for the energy intensive chemical industry in the Netherlands. Master's thesis.

Da-li, G., 2009. Energy service companies to improve energy efficiency in China: barriers and removal measures. The 6th International Conference on Mining Science \& Technology. Procedia Earth and Planetary Science 1, 1695-1704.

DEA, 2002: Energy Management in Industry. Danish Experiences. Edited by Danish Energy Authority.

http://www.ens.dk/sites/ens.dk/files/dokumenter/publikationer/downloads/energy_manag ement.pdf Accessed August 16, 2013.

EC, 12/11/2012: Directive 2012/27/EU of the European Parliament and of the Council of 25 October 2012 on energy efficiency, amending Directives 2009/125/EC and 2010/30/EU and repealing Directives 2004/8/EC and 2006/32/EC.

EIPPCB, 2009. Reference Document on Best Available Techniques for Energy Efficiency. http://eippcb.jrc.ec.europa.eu//reference/BREF/ENE_Adopted_02-2009.pdf. Accessed June 23, 2013.

Fleiter, T., Schleich, J., Ravivanpong, P., 2012. Adoption of energy-efficiency measures in SMEs-An empirical analysis based on energy audit data from Germany. Energy Policy $51,863-875$.

Fleiter, T., Worrell, E., Eichhammer, W., 2011. Barriers to energy efficiency in industrial bottom-up energy demand models—A review. Renew. Sustain. Energy Rev. 15, 30993111.

Foddy, W., 2003. Constructing questions for interviews and questionnaires. Theory and practice in social research. Cambridge Univ. Press, Cambridge.

Galitsky, C., Martin, N., Worrell, E., Lehman, B., 2003. Energy Efficiency Improvement and Cost Saving Opportunities for Breweries. An ENERGY STAR® Guide for Energy and Plant Managers.

Groot, H.L. de, Verhoef, E., Nijkamp, P., 2001. Energy saving by firms: decision-making, barriers and polices. Energy Econ. 29 868-888, 717-740.

Gorard, S., 2003. Quantitative Methods in Social Science. New York: Continuum.

Harris, J., Anderson, J., Shafron, W., 2000. Investment in energy efficiency: a survey of Australian firms. Energy Policy 28, 867-876.

Hirst, E., Brown, M.A., 1990. Closing the efficiency gap: barriers to the efficient use of energy. Resour. Conserv. Recycl., 267-281.

IEA, 2011. World energy outlook 2011. OECD, Paris.

Jaffe, A.B., Stavins, R.N., 1994. The energy paradox and the diffusion of conservation technology. Resour. Energy Econ. 16, 91-122.

Jamieson, S., 2004. Likert scales: how to (ab)use them. Med. Educ. 38, 1217-1218.

Jernkontoret, 2011. Members of Jernkontoret, steel companies and plants 2011. http://www.jernkontoret.se/ladda_hem_och_bestall/publikationer/stal_och_stalindustri/for etag_och_prod.anlaggningar/sss_adr_eng.pdf. Accessed August 15, 2013.

Johansson, M.T., Söderström, M., 2011. Options for the Swedish steel industry - Energy efficiency measures and fuel conversion. Energy, 191-198.

Leung, W.-C., 2001. How to design a questionnaire. Student BMJ 9, 187-189.

Nagesha, N., Balachandra, P., 2006. Barriers to energy efficiency in small industry clusters: Multi-criteria-based prioritization using the analytic hierarchy process. Energy 31, 19691983. 
Nowell, D., 2011. The Ruination of the Likert Scale. Save the Likert Scale before it's too late! http://www.psychologytoday.com/blog/intrinsic-motivation-and-magicalunicorns/201111/the-ruination-the-likert-scale. Accessed August 15, 2013.

Okazaki, T., Yamaguchi, M., 2011. Accelerating the transfer and diffusion of energy saving technologies steel sector experience-Lessons learned. Energy Policy 39, 1296-1304.

Painuly, J., Park, H., Lee, M.-K., Noh, J., 2003. Promoting energy efficiency financing and ESCOs in developing countries: mechanisms and barriers. J. Clean. Prod. 11, 659-665.

Palm, J., Thollander, P., 2010. Interdisciplinary perspective on industrial energy efficiency. Applied Energy 87, 3255-3261.

Pratt, M.G., 2007. Fitting Oval Pegs into Round Holes: Tensions in Evaluating and Publishing Qualitative Research in Top-Tier North American Journals. Organ. Res. Methods 11, 481-509.

Reddy, B.S., 2013. Barriers and drivers to energy efficiency - A new taxonomical approach. Energy Convers. Manag. 74, 403-416.

Reiczigel, J., Zakariás, I., Rózsa, L., 2005. A Bootstrap Test of Stochastic Equality of Two Populations. Am. Stat. 59, 156-161.

Ren, T., 2009. Barriers and drivers for process innovation in the petrochemical industry: A case study. J. Eng. Technol. Manag. 26, 285-304.

Roberson, P., Schema, S., Mundfrom, D., Holmes, T., 1995. Analysis of Paired Likert Data: How to Evaluate Chance and Preference Questions. Fam. Med. 10, 672-677.

Rohdin, P., Thollander, P., 2006. Barriers to and driving forces for energy efficiency in the non-energy intensive manufacturing industry in Sweden. Energy 31, 1836-1844.

Rohdin, P., Thollander, P., Solding, P., 2007. Barriers to and drivers for energy efficiency in the Swedish foundry industry. Energy Policy 35, 672-677.

Sandberg, P., Söderström, M., 2003. Industrial energy efficiency: the need for investment decision support from a manager perspective. Energy Policy 31, 1623-1634.

Sardianou, E., 2008. Barriers to industrial energy efficiency investments in Greece. J. Clean. Prod. 16, 1416-1423.

Satchwell, A., Goldman, C., Larsen, P., Gilligan, D., Singer, T., 2010. A Survey of the U.S. ESCO Industry: Market Growth and Development from 2008 to 2011. http://emp.lbl.gov/sites/all/files/REPORT\%20lbnl-3479e.pdf. Accessed April 3, 2014.

SEA, 2013. Energy in Sweden 2011. http://www.energimyndigheten.se/. Accessed August $15,2013$.

Shi, H., Peng, S., Liu, Y., Zhong, P., 2008. Barriers to the implementation of cleaner production in Chinese SMEs: government, industry and expert stakeholders' perspectives. J. Clean. Prod. 16, 842-852.

Sivill, L., Manninen, J., Hippinen, I., Ahtila, P., 2013. Success factors of energy management in energy-intensive industries: Development priority of energy performance measurement. Int. J. Energy Res. 37, 936-951.

Soroye, K.L., Nilsson, L.J., 2010. Building a business to close the efficiency gap: the Swedish ESCO Experience. Energy Effic. 3, 237-256.

Sorrell, S., O'Malley, E., Schleich, J., Scott, S., 2004. The Economics of Energy Efficiency - barriers to cost effective investment. Cheltenham, UK: Edward Elgar Publishing.

Sorrell, S., Schleich, J., Scott, S., O'Malley, E., Trace, F., Boede, U., Ostertag, K., Radgen, P., 2000. Reducing barriers to energy efficiency in public and private organizations, Brighton, UK.

Stenqvist, C., Nilsson, L.J., Ericsson, K., Modig, G., 2011. Energy management in Swedish pulp and paper industry - the daily grind that matters, in: Lindström, T. (Ed.), Energy efficiency first: the foundation of a low-carbon society. ECEEE 2011 Summer Study; 
Conference proceedings; 6 - 11 June 2011, Belambra Presqu'île de Giens, France. ECEEE, Stockholm.

Thollander, P., Danestig, M., Rohdin, P., 2007. Energy policies for increased industrial energy efficiency: Evaluation of a local energy programme for manufacturing SMEs. Energy Policy 35, 5774-5783.

Thollander, P., 2008. Towards increased energy efficiency in Swedish industry. Barriers, driving forces \& policies. Dissertation. Linköping University.

Thollander, P., Ottosson, M., 2008. An energy efficient Swedish pulp and paper industry exploring barriers to and driving forces for cost-effective energy efficiency investments. Energy Effic. 1, 21-34.

Thollander, P., Ottosson, M., 2010. Energy management practices in Swedish energyintensive industries. J. Clean. Prod. 18, 1125-1133.

Thollander, P., Backlund, S., Trianni, A., Cagno, E., 2013. Beyond barriers - A case study on driving forces for improved energy efficiency in the foundry industries in Finland, France, Germany, Italy, Poland, Spain, and Sweden. Applied Energy 111, 636-643.

Trianni, A., Cagno, E., 2012. Dealing with barriers to energy efficiency and SMEs: Some empirical evidences. Energy 37, 494-504.

Trianni, A., Cagno, E., Thollander, P., Backlund, S., 2013a. Barriers to industrial energy efficiency in foundries: a European comparison. J. Clean. Prod. 40, 161-176.

Trianni, A., Cagno, E., Worrell, E., 2013b. Innovation and adoption of energy efficient technologies: An exploratory analysis of Italian primary metal manufacturing SMEs. Energy Policy 61, 430-440.

Trianni, A., Cagno, E., Worrell, E., Pugliese, G., 2013c. Empirical investigation of energy efficiency barriers in Italian manufacturing SMEs. Energy 49, 444-458.

Trygg, L., Karlsson, B.G., 2005. Industrial DSM in a deregulated European electricity market - a case study of 11 plants in Sweden. Energy Policy 33, 1445-1459.

Trygg, L., Thollander, P., Backlund, S., Olsson, L., 2010. Sustainable energy systems in practice - implementation of energy efficiency in industry [Uthålliga energisystem i praktiken - implementering av energieffektivitet inom industrier].

Venmans, F., 2014. Triggers and barriers to energy efficiency measures in the ceramic, cement and lime sectors. J. Clean. Prod. 69, 133-142.

Vine, E., 2005. An international survey of the energy service company (ESCO) industry. Energy Policy 33, 691-704.

Walsh, C., Thornley, P., 2012. Barriers to improving energy efficiency within the process industries with a focus on low grade heat utilisation. J. Clean. Prod. 23, 138-146.

Weber, L., 1997. Some reflections on barriers to the efficient use of energy. Energy Policy 25, 833-835.

Wentemi Apeaning, R., Thollander, P., 2013. Barriers to and driving forces for industrial energy efficiency improvements in African industries - a case study of Ghana's largest industrial area. J. Clean. Prod. 53, 204-213.

Worrell, E., Blinde, P., Maarten, N., Blomen, E., Masanet, E., 2010. Energy Efficiency Improvement and Cost Saving Opportunities for the U.S. Iron and Steel Industry. An ENERGY STAR® Guide for Energy and Plant Managers. Berkeley, USA.

Worrell, E., Ruth, M., Laitner, J.A., Finman, H., 2001. Productivity benefits of industrial energy efficiency measures. Berkeley and Washington, USA.

Yin, R.K., 2003. Case study research. Design and methods, 3rd ed., Thousand Oaks, CA: Sage. 